IRSH 63 (2018), pp. 273-319 doi:10.1017/So0208590I 8000329

(C) 20 I 8 Internationaal Instituut voor Sociale Geschiedenis

\title{
Historicizing Precarious Work: Forty Years of Research in the Social Sciences and Humanities
}

\author{
Elois A B ETT I \\ Department of History and Cultures, University of Bologna \\ Piazza San Giovanni in Monte 2, 40124 Bologna, Italy*
}

E-mail: eloisabetti@gmail.com

\begin{abstract}
AвSTRACT: This survey article seeks to contribute to the understanding of the concepts of precarious work and precarization in the history of industrial capitalism by addressing the debate in the social sciences and humanities over the past forty years. Based on a gendered global approach, this article aims to offer a critique of the Global North-centric perspective, which largely conceives precarious work as a new phenomenon lacking a longer historical tradition. The first part discusses the multiple origins, definitions, and conceptualizations of "precarious work" elaborated with regard to industrial as well as post-industrial capitalism, taking into account selected contemporary sources as well as studies conducted by historians and social scientists. In the second part, the influence of different approaches, such as the feminist and post-colonial ones, in globalizing and gendering the precarious work debate is examined in their historical contexts, exploring also the crucial nexus of precarious work and informal work. In the conclusion, the limitations of the available literature are discussed, along with suggestions for further directions in historicizing precarious work from a global perspective.
\end{abstract}

\section{INTRODUCTION}

Nowadays, "precarious work" is a highly controversial topic in the political and economic debate concerning labour matters within national and international institutions and organizations, such as the International Labour Organization (ILO). In recent decades, a growing number of surveys and studies have shown that precarious work has become one of the main social issues worldwide, particularly for younger generations, less protected workers such as migrants, and the female workforce. According to the ILO,

\footnotetext{
* This article has benefited from a European Institute of Advanced Study (EURIAS) Fellowship at the Institute for Human Sciences of Vienna, supported by the European Commission, MarieSklodowska-Curie Actions - COFUND Programme - FP7. I wish to thank the following scholars for their comments and suggestions on the previous versions of this article: Sara Bernard, Luisa Bialasiewicz, Aad Blok, Eileen Boris, Christian De Vito, Ella Klik, János M. Kovács, Steven Lukes, David Mayer, Shalini Randeria. Please note that a bibliography with full references is included at the end of this article.
} 
the global economic crisis of 2008 heightened the level of labour insecurity worldwide, entrapping more and more categories of workers in what is increasingly labelled precarious jobs, both in the Global North and the

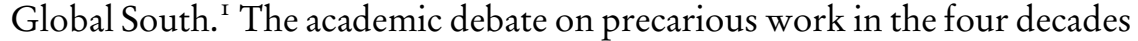
considered in this article has been influenced by the spread of the phenomenon of precarious work and its perception by social actors, who started to mobilize against it in the new millennium, adopting resourceful and often pioneering forms of resistance. ${ }^{2}$ Before the early 2000 , precarious work was hardly considered as a subject of investigation, due to the conceptualization, by neoliberal economists and politicians, of "flexibility" and "flexible labour" - important aspects of precarious work - as positive challenges to capitalist systems, deemed necessary to increase employment levels and business competitiveness. Until this time, the use of the precarious work concept had remained limited to the academic debate, as it had been regarded as a contested and highly "politicized" term. ${ }^{3}$ The 2008 global recession led to a change. Since the outbreak of this economic crisis, a growing number of studies have been produced independently within academia as well as under the aegis of institutional bodies, especially the European Union (EU). The 2016 study on Precarious Employment in Europe, commissioned by the European Parliament, testifies not only to the increasing concern of EU institutions about the phenomenon of precarious work, but also to the final adoption of the concept as a relevant and accepted analytical tool. ${ }^{4}$ In the past few decades, social scientists, economists, and legal experts mainly considered precarious work a new phenomenon and a characteristic feature of post-industrial society, emerging in the 1980 s after the breakdown of Fordism.

More recently, however, several historical studies have questioned the novelty of job precarity, showing how forms of precarious work have characterized the entire history of industrial capitalism, both in the Global North and the Global South. According to some interpretations, precarious work is the "norm" of capitalism, while the so-called standard employment model, characterized by full-time, long-term employment with a single employer, should be viewed as a historical exception, predominant throughout Western countries only in the third quarter of the twentieth century. ${ }^{5}$

I. ILO, The changing Nature of Jobs.

2. On resistance against precarious work, see, amongst others: Mattoni, Media Practices and Protest Politics; Della Porta et al., The New Social Division; Lambert and Herod, Neoliberal capitalism and Precarious Work; Johnson, Precariat; Procoli, Workers and Narratives of Survival in Europe; Milkman and Ott, New Labor in New York; Gleeson, Precarious Claims.

3. For an overview of the use of the concept in Western Europe until the early 2000s: Düll, Defining and Assessing Precarious Employment in Europe.

4. European Parliament, Directorate-General For Internal Policies, Policy Department A, Precarious Employment in Europe.

5. Breman and Van der Linden, "Informalizing the Economy". 
By adopting a gendered global perspective, this article challenges the still hegemonic Western approach prevalent in the literature and seeks to contribute to the understanding of precarious work as a historical phenomenon characterizing different phases of industrial capitalism. First, it shows that the model of capitalism prevailing in the literature is the Western European and North American one, and that other models are being generally ignored. Secondly, it points out that the debate on precarious work has focused predominantly on wage work and has not related it to informal work, which is crucial to understanding the very existence of job precariousness in the Global South. Thirdly, it underlines the fact that the forms and the extent of precarious work in economic sectors other than the Western industrial sector are still under-researched. This has prevented an understanding, for instance, of the long-existing nexus of precariousness and informality in a key sector such as agriculture. Finally, this article argues that, by concentrating on the Western European and North American path as the hegemonic one, the implications of the concept of "variations of capitalism" in determining different trajectories of precarity/stability across time and space have rarely been taken into account. ${ }^{6}$ A global gendered approach is crucial to understanding how precarious work affected male, female, and child labour differently across time and space, thereby challenging the idea of precarious work as a new, recent phenomenon. Moreover, it demonstrates that the very existence of job precariousness was not perceived and conceptualized as such until it started affecting the Western male breadwinner in core industrial sectors during the far-reaching process of deindustrialization experienced by European and North American countries in industrial capitalism. ${ }^{7}$

The first part of the article addresses the multiple origins, definitions, and conceptualizations of precarious work in the history of industrial and post-industrial capitalism, taking into account selected contemporary sources as well as studies conducted by historians and social scientists. The first subsection examines how precarious work has been conceptualized in, and vis-à-vis, nineteenth- and twentieth-century industrial societies, while the second subsection provides a selective overview of the studies addressing the resurgence of precarious work in post-industrial societies after the economic crisis of the I970s. As language is particularly significant in this context, the relationship between job flexibility and job precariousness is investigated.

The second part explores the contributions provided by different approaches, such as feminist scholarship and Global South studies, in

6. On variations/varieties of capitalism: Hall and Soskice, Variations of Capitalism; Thelen, Varieties of Liberalization.

7. On the relationship between deindustrialization and the decline of job stability: Emmenegger et al., The Age of Dualization. 


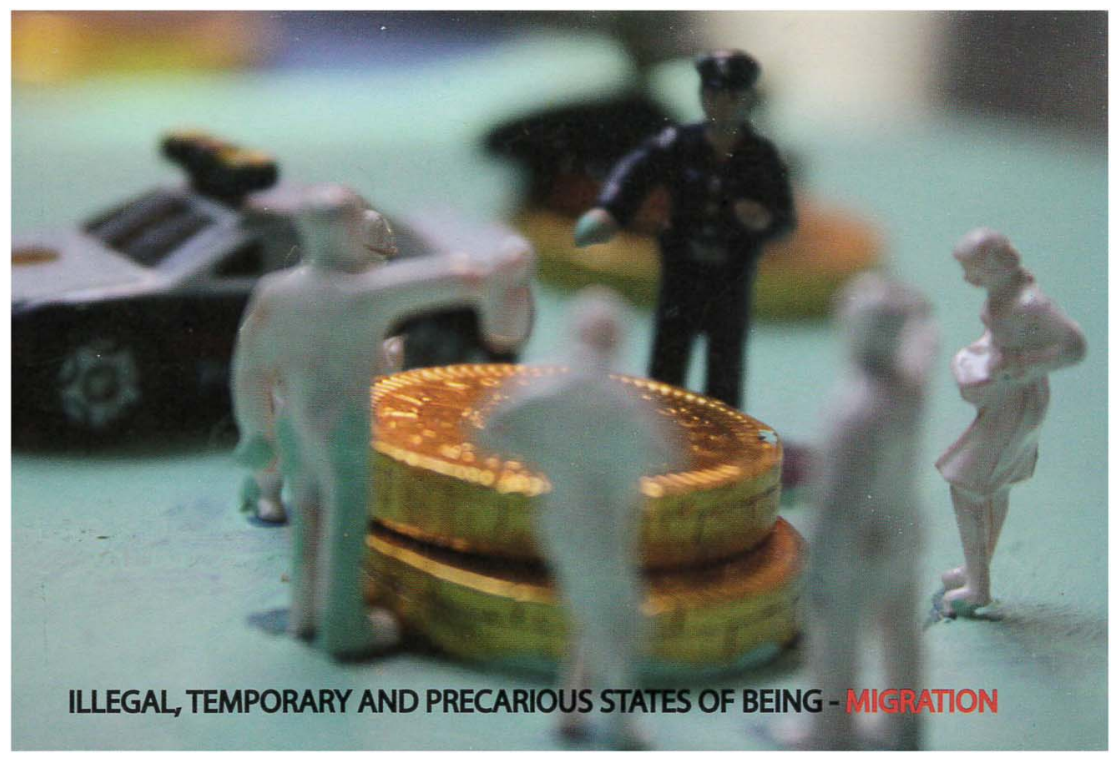

Figure I. Postcard for the exhibition "Illegal, temporary and precarious states of being: migration” (Bangkok, Pridi Bhanomyong Institute, Feb. I 5-28, 2010).

IISH collection.

gendering and globalizing the precarious work debate. The first subsection shows how the intersection of gender, class, race, and citizenship has played a crucial role in the variations of precarity and stability in the history of industrial as well as post-industrial societies. The second subsection investigates the influence of transnational studies, the informality debate, and Global South perspectives on globalizing precarious work. The latest stage of globalization, as well as its critics, have impacted the precarious work debate and have produced a shift from the still hegemonic Western conceptualization towards a broader perspective, which includes the consideration of the former Communist countries jointly with the Global South.

The conclusion seeks to explain and discuss the limitations of the available literature, while suggesting some additional perspectives and concepts to be included in the precarious work debate.

\section{ORIGINS AND CONCEPTS OF PRECARIOUS WORK IN THE HISTORY OF INDUSTRIAL CAPITALISM}

\section{Precarious work in industrial societies}

Writing a "genealogy" of the concept of precarious work has attracted the attention of numerous scholars in the past two decades, especially 
sociologists. ${ }^{8}$ Only a few of them, however, have placed the concept of precarious work in the longer history of industrial capitalism or in the precapitalist era. Indeed, the conceptualizations of precarious work provided by social scientists from the late i970s onwards were mainly related to the spread of the so-called "flexible labour arrangement" in the Western labour market, conceived as one of the major changes occurring in the transition from Fordism to Post-Fordism. Yet, the genealogy of the concept can be traced back much further, as suggested by contemporary sources and historical studies.

From a linguistic standpoint, Jean-Claude Barbier places the origin of the terms "precariousness/precarious" in the common Latin root precor (pray) or precarius (obtained by praying), dating back to the late Middle Ages or the Early Modern era, depending on the specific country considered. ${ }^{9}$ Also, historians like Marcel van der Linden have adopted the perspective of the longue durée, taking into account the categories of the casual poor and of casualized wage labour to trace the origins of precarity from Ancient Greece to the present. ${ }^{10}$

Although the term "precariousness" is not new, according to Barbier, it started to be more frequently associated with employment and welfare matters in the major European countries only after 1 945. But Marcel van der Linden shows that the concept was used to refer to workers' conditions as early as I $840 .{ }^{\text {II }}$ The French economist and sociologist Eugène Buret adopted the term précaire (precarious) in his book De la misère des classes laborieuses en Angleterre et en France. ${ }^{\mathrm{I} 2}$ With the rise of the social question in the nineteenth century, engaged intellectuals, especially from the socialist milieu, adopted the term as such or used a similar concept to draw attention on the precarious lives and work of the proletariat and the lumpenproletariat.

Looking at the Marxian tradition, evidence of the use of precarious/ precariousness can be found in Friedrich Engels's Condition of the Working Class in England (1 845), in Karl Marx and Friedrich Engels's Communist Manifesto, and even in Marx's Capital. ${ }^{13}$ The precariousness of workers'

8. In addition to the works of Barbier (cited below), see the following for examinations of the concept of precariousness/precarity/precarious: Faguer, "Pour une histoire de la précarité"; Neilson and Rossiter, "Precarity as a Political Concept"; Candeias, "Genealogie des Prekariats"; Vultur, "La précarité. Un "concept fantôme"; Quinlan, The "Pre-Invention" of Precarious Employment; Munck, "The Precariat: A View from the South"; Casas-Cortés, "A Genealogy of Precarity"; Motakef, Prekarisierung; Jonna and Foster, "Marx’s Theory of Working-Class Precariousness"; Millar, "Toward a Critical Politics of Precarity"; Hewison, "Precarious Work".

9. Barbier, 'Precariousness' of Employment; idem, "La précarité, une catégorie française"; idem, "There Is More to Job Quality than 'Precariousness"; idem, "Employment Precariousness".

ı. Van der Linden, "San Precario".

I I. Idem, "Robert Castel's Les métamorphoses".

I 2. Buret, De la misère des classes laborieuses.

I 3. Engels, The Condition of the Working Class in England; Marx, Das Kapital; idem and Engels, Manifest der Kommunistischen Partei. 
conditions was explicitly mentioned by William Morris in 1883 in his Signs of Change. ${ }^{\mathrm{I}}$ Social reformers like Henry Mayhew and Charles Booth addressed in their enquiries the "precarious" working and living conditions of Londoners. ${ }^{15}$ A series of articles published by the socialist journalist Adolphe Smith and the photographer John Thomson described the life of London's street workers as "precarious". ${ }^{16}$ The concept was also used by Sidney Webb in 1887 in his Facts for Socialists. ${ }^{17}$ In latecomer countries such as Italy, the concept of precariousness emerged as well in the enquiries conducted by the establishment and governmental authorities: by Franchetti and Sonnino concerning Sicily, Nitti, and Zanardelli concerning Calabria and Basilicata, and the Jacini investigations of the conditions of rural workers. ${ }^{18}$

Contemporary observers of the nineteenth and early twentieth centuries, however, hardly distinguished precarious working conditions from the precariousness of the working-class existence as such, and they closely associated the latter with the more general issue of pauperism. This was also the case of post-World War II social studies and analyses, as shown by Dorothy Day's article on "Poverty and Precarity" (1952) in the United States or the parliamentary enquiry into poverty (I95 I) in the case of Italy. ${ }^{19}$ Underemployment and low salaries were considered responsible for precarious working-class conditions even in the late i940s and early i950s, when full and steady employment was a shared goal at a global level.

The initial attempt at a conceptualization of precarious work and precariousness came a while later, and it happened, somewhat ironically, in the I960s, when job stability was beginning to be considered the norm of the "affluent society". In 1964, the Italian economist Paolo Sylos Labini devoted an article to the analysis of precarious employment in Sicily, advocating the relevance of such a concept for studying developing countries and regions. ${ }^{20}$ In his 1974 book on the social classes in Italy, ${ }^{21}$ he associated precarious work with the Marxian concept of the lumpenproletariat, considering precarious work as a consequence of the Italian economic divide between the industrialized Northern regions and the underdeveloped Southern ones. Precarious workers were identified as low-income casual workers with a highly unstable employment

I4. Morris, Signs of Change.

I s. Mayhew, London Labour and the London Poor; Booth, Life and Labour of the People in London.

I6. Thomson and Smith, Street Life in London.

17. Webb, Facts for Socialists.

18. Zanardelli, Inchiesta sulla Basilicata; Franchetti and Sonnino, La Sicilia nel I876; Jacini, Relazione finale sui risultati dell'inchiesta agraria.

19. Day, Poverty and Precarity; Pesenti, Sottoretribuzione e miseria.

20. Sylos Labini, "Precarious Employment in Sicily".

2 I. Idem, Saggio sulle classi sociali. 
relationship, usually working in small industrial shops, but also in agriculture and retail.

In the same period, Pierre Bourdieu, in his well-known study Travail et travailleurs en Algérie, used the concept of précarité to describe the conditions of "unstable" Algerian workers, whom he also associated with the lumpenproletariat. ${ }^{22}$ In Bourdieu's discourse, the condition of precarity and its opposite, stability, were associated with the capitalistic transformation of Algerian traditional society and the rise of a more dualistic labour market, formed by a minority of stable workers employed in the modern sector and a diverse group of unemployed or underemployed journeymen experiencing unstable working and life conditions.

Thanks to the development and institutionalization of social and labour history in the second half of the twentieth century, a growing number of historical studies focused on the nineteenth- and early twentieth-century working class, revealing its structural precariousness. ${ }^{23}$ Social and labour historians usually adopted concepts such as "unstable" and "casual" to address those working conditions that, today, are labelled "precarious". ${ }^{24}$ With the rise of feminist studies, female labour historians provided a crucial contribution to the understanding of the diverse levels of precarity (and stability) affecting the early working class by casting light on its gendered composition and diverse paths. ${ }^{25}$ "Instability" became a crucial category of analysis to investigate women's working conditions in the modern age, whereas the term precarious/precariousness was rarely applied until the new millennium. ${ }^{26}$

On the theoretical level, studies by Immanuel Wallerstein, especially Historical Capitalism, ${ }^{27}$ have underscored that the existence of an industrial proletariat, employed permanently and paid wages, on time, depended on both the needs of the employers in the different phases of industrialization

22. Bourdieu, Travail et travailleurs en Algérie; on Bourdieu, see also Rapini, "Can Peasants Make a Revolution?”.

23. Hobsbawm, "The Machine Breakers"; Thompson, The Making of the English Working Class; Perrot, Les ouvriers en grève; Merli, Proletariato di fabbrica e capitalismo industriale; De Clementi, "Appunti sulla formazione della classe operaia in Italia"; Piva, "Classe operaia e mobilità del lavoro in fabbrica”; Bigazzi, Il Portello.

24. See, for instance, Knotter, "Poverty and the Family-Income Cycle"; for an overview, see: Van Der Linden, "San Precario"; Betti, La precarietà del lavoro.

25. See, for instance: Tilly, "Paths of Proletarianization"; Pieroni Bortolotti, "Le lotte delle sigaraie fiorentine"; Cattaruzza, La formazione del proletariato urbano; Botz, Die Fran in der Arbeiterbewegung; Müller et al., Strukturwandel der Frauenarbeit 1880-1980; Cantor and Laurie, Class, Sex and the Woman Worker; Kessler-Harris, Out of Work; Perrot, "Travaux de femmes dans la France du XIXe siècle".

26. Among the few feminist labour historians adopting the concept of precariousness were Boris and Dodson, "Working at Living"; Komlosy, "Work and Labour Relations"; Bonfiglioli, "Gender, Labour and Precarity".

27. Wallerstein, Historical Capitalism. 
and the nature of their products. Since the first industrial revolution, employers tended to organize the labour force according to their product market, trying to offload onto the weakest part of the labour force (i.e. women and children) the risks related to their entrepreneurial activity.

While neither the contemporary observers of the early working class, nor the twentieth-century historians provided comprehensive definitions of precarious work and job precariousness, historians from the 2000 s onwards increasingly started to use these concepts to analyse workers' conditions in nineteenth- and twentieth-century industrial capitalism. The perpetuation of similar forms of precarious work from the late nineteenth to the midtwentieth centuries, despite the changes in the organization of work and production, clearly emerges from the studies by Sophie Beau on the department stores of Lyons ${ }^{28}$ and by Augusto De Benedetti on glovemaking in Naples. ${ }^{29}$ The same perspective is applied in the recent work of Marc Leleux, who retraces forms of precarious work in the industrial development of Northern France from the mid-nineteenth century to the early twentieth century. ${ }^{3 \circ}$

The conceptualization of job precariousness and precarious work that we are familiar with has been mainly elaborated in contrast to the normative standard employment model of the affluent Western society of the I950sI970s. ${ }^{3 \mathrm{I}}$ It is not surprising, then, that few social scientists, historians, and even contemporary social actors adopted the concept of precarious/precariousness/precarity to investigate the working conditions during the Fordist era. ${ }^{32}$ This was considered to be the main period of job stability in the history of industrial capitalism, as opposed to the generalized job instability of the nineteenth and early twentieth centuries..$^{33}$

A relevant exception, never previously acknowledged, is the study published in the early I 980 s by the Italian political scientist (and novelist) Valerio Evangelisti, who adopted the concept of the precariat (precariato) in identifying the rural proletariat of the late nineteenth and early twentieth centuries as well as the "Fordist" industrial proletariat of the communist-led EmiliaRomagna region. ${ }^{34}$ Evangelisti's empirical study contributed to showing the

28. Beau, Un siècle d'emplois précaires.

29. De Benedetti, Il masso di Sisifo, pp. 167-222.

30. Leleux, Aux sources de la précarité; Leleux, Histoire des sans-travail et des précaires du Nord. 3I. This debate has been reconstructed in Betti, "Gender and Precarious Labor"; see also Breman and Van der Linden, "Informalizing the Economy".

32. Evidence from the Italian case has revealed that female trade unionists and female leaders of left-wing organizations were among the first to acknowledge the phenomenon of job precariousness during the Fordist era, among them the communist trade unionist Donatella Turtura. See Turtura, Per nuove più avanzate conquiste delle lavoratrici italiane.

33. See, for instance: Crafts, Toniolo, Economic Growth in Europe since 1945; Armstrong, Glyn, and Harrison, Capitalism Since World War II; Boltho, The European Economy.

34. Evangelisti, Sechi, Il galletto rosso. 
existence of job precariousness within the allegedly "Fordist" working class, which more recent research has corroborated.

In the past two decades, the concept of precariousness has also been used with a wider and more existential meaning, usually by adopting the neologism precarity. It was again Pierre Bourdieu who used the term précarité to address the transformation of society resulting from globalization and neoliberalism, stating that, in the given circumstances, everybody was precarious . ${ }^{35}$ In Judith Butler's view, the concept of precarity "focuses on the conditions that threaten life in ways outside of one's control". ${ }^{6}$ The concept of the "precariat", widespread after the publication of Guy Standing's book, ${ }^{37}$ is also part of the debate on precariousness at large. Defined as a class-in-the-making, whose members have insecure labour relationships and no long-term employment contracts, the very concept of precariat has been contested by scholars such as Jan Breman. The latter addressed the precariat as a "bogus concept" for several reasons, amongst them the North-centric approach, the artificial division between the proletariat and the precariat, the lack of historical perspective, and the very definition of the precariat as a class-to-be. ${ }^{38}$

The subsequent attempts to provide a comprehensive definition of precarious work/precariousness have revealed to what extent the concept has played an increasingly important role in the debate of labour issues in the past three decades. The difficulty in reaching a shared and formalized definition of precarious work/precarious employment, however, testified to the institutional reluctance of adopting as a key concept a notion that was considered highly political, was related to social movements, and was contrary to the mainstream employment policies that were based on the paradigm of labour flexibility. The following subsection will reconstruct some aspects of this controversy.

\section{(Re)Discovering precarious work in post-industrial societies}

The economic crisis of the 1970 and its social consequences played a major role in triggering the debate, since the 1980 , on precarious work and job precariousness, first in Western Europe and later in the North American context. The conceptualizations of precarious work in the social sciences were closely related to the spread of the so-called flexible labour arrangement in Western labour markets, conceived as one of the major changes in the wake of the 1970 c crisis. As pointed out by scholars such as Jan Breman,

35. Bourdieu, La précarité est aujourd'hui partout.

36. Butler, "Performativity, Precarity and Sexual Politics", p. i; see, in addition: Butler, Precarious Life.

37. Standing, The Precariat.

38. Breman, “A Bogus Concept?”. 
Marcel van der Linden, Ronaldo Munck, Brett Neilson, and Ned Rossiter, ${ }^{39}$ the concept of precarious work was elaborated in contrast to the so-called standard employment model, which was considered to be the standard employment relationship in the West. The collapse, but also the resilience, of the standard employment model were closely connected with the spread of job flexibility and the (new) rise of precarious work in the literature of the 1980 and 1990 discussed below.

Both in Italy and Spain, the rise of job precariousness was mainly associated with the decentralization of industrial production and the spread of subcontractors, industrial homework, and undocumented work. ${ }^{4}$ In France, the concept of precarious work could mainly be found in family and poverty studies, as "atypical" employment situations were seen as the primary source of precarious living conditions. ${ }^{{ }^{\mathrm{I}}}$ Between the second half of the I970s and the early I 980 s, terms such as emplois précaires/précarité de l'emploi (French), lavoro precario/precarietà del lavoro (Italian), empleo and trabajo precario/ precaridad laboral (Spanish) entered the academic debate in the respective countries. However, only from the early 2000 s onwards were the terms "precarious work/employment" and "job/labour precariousness" frequently used, indicating that the precarious work debate was not yet as developed in the English-speaking countries ${ }^{42}$ as it was in the Mediterranean ones, with the significant exception of Canada. ${ }^{43}$ In Germany as well, it was only around the beginning of new millennium that the concept of Prekariat/Prekarität and prekäre Arbeit became increasingly common in scholarly debates. ${ }^{44}$

39. Idem and Van der Linden, "Informalizing the Economy"; Munck, "The Precariat: A View from the South"; Neilson and Rossiter, "Precarity as a Political Concept".

40. On I 980 S Spanish studies dealing with precarious work, see: Castillo and Prieto, Condiciones de trabajo; Recio, "Flexibilidad, eficiencia y desigualdad"; Alós, Míguelez and Recio, El trabajo precario en el comercio; Sánchez Moreno and Cutanda Tarín, Segmentación, flexibilidad y precarización. On I970s Italian studies adopting the concept of precarious work, see: Paci, Mercato del lavoro e classi sociali; Meldolesi, Disoccupazione ed esercito industriale; Brusco, "Organizzazione del lavoro"; Frey, Lavoro a domicilio e decentramento.

4I. On French early studies on precarity, see: Pitrou, La vie précaire; Pitrou, Vivre sans famille?; Linhart and Maruani, "Précarisation et déstabilisation des emplois ouvriers".

42. For an overview of the precarious work debate in the British context, Düll, Defining and Assessing Precarious Employment in Europe; in the US context, the discussion on precarious work as such exploded after the publication of Kalleberg, Good Jobs, Bad Jobs, which was preceded by Kalleberg, "Precarious Work, Insecure Workers". In the Australian context, studies can be found since the late I990s; for an overview, see: Burgess and Campbell, "The Nature and Dimensions of Precarious Employment"; on the development in the new millennium: Tweedie, "Precarious Work and Australian Labour Norms".

43. Studies on precarious work in Canada have been conducted since the late ig9os: Schellenberg and Clarke, Temporary Employment in Canada; Rose, "Economic Restructuring"; Vosko, Temporary Work.

44. For an overview of the German debate on precarious work, see: Brinkmann, Dörre, and Röbenack, Prekäre Arbeit; Altenhain et al., Von 'Neuer Unterschicht' und Prekariat.; Castel and Dörre, Prekarität, Abstieg, Ausgrenzung. 
The importance of the flexibility model in the management of employees by enterprises, ${ }^{45}$ and its part of the government employment strategy to reduce unemployment ${ }^{46}$ triggered a new strand of economic studies in the I980s. The relationship between labour market (de)regulation, flexibility, and precarious work was explicitly addressed by the French economist Guy Caire in his 1982 article "Précarisation des emplois et régulation du marché du travail". ${ }^{47}$ Moreover, the volume La flexibilité du travail en Europe, co-edited by the French regulationist economist Robert Boyer, ${ }^{48}$ and the paper Labour Flexibility: Cure or Cause for Unemployment?, written by Guy Standing, ${ }^{49}$ at the time employed at the ILO, investigated the effects of job flexibility.

Since the mid-I 980 s, however, other attempts to conceptualize precarious work were made in Latin America, where the Inter-American Centre for Labour Administration (CIAT-OIT), an ILO facility in Lima, Peru, and the Argentinian Ministry of Labour and Social Security promoted the joint study El empleo precario in Argentina. ${ }^{\circ}$ In 1980 s Latin America, the conceptualization of precarious work was already very much related to the ideal of industrial wage labour and the standard employment relationship, in spite of the prevailing informality of labour relationships in the continent. The precarization process was addressed as a consequence of the labour market reform of the I970s, promoted in Latin America under the influence of neoliberal economic policies during the various military dictatorships. Flexible labour arrangements, such as temporary work, parttime work, temporary agency work, sub-contracting, and undocumented work, including industrial homeworking, were considered to be the main forms of job precarity.

In the late I980s, Gerry and Janine Rodgers' book Precarious Jobs in Labour Market Regulation provided the most influential and long-lasting conceptualization of precarious work, introducing the concept of

45. Pioneering works on the so-called flexible firms are: Atkinson, "Manpower Strategies for Flexible Organisations"; Atkinson and Meager, Changing Work Patterns.

46. On the 1980 s discussion about the role of "flexibility" in the labour market, see: OECD, Flexibility in the Labour Market; Piore, "Perspectives on Labor Market Flexibility"; Rosenberg, From Segmentation to Flexibility; Tarling, Flexibility in the Labour Markets; Meulders and Wilkin, "Labour Market Flexibility"; Pollert, Farewell to Flexibility; on the relationship between the state and labour market flexibility in Western countries, see: Rosenberg, "Labor Market Restructuring in Europe and the United States"; on labour market flexibility in I980s Japan, see also: Koshiro, Employment Security and Labor Market Flexibility; on the relationship between flexibility and the Fordism/post-Fordism debate, see: Burrows, Gilbert and Pollert, Fordism and Flexibility.

47. Caire, "Précarisation des emplois"; Offredi, "La précarité des années quatre-vingt".

48. Boyer and Wolleb, La flexibilité du travail en Europe.

49. Standing, "Labour Flexibility: Cause or Cure for Unemployment?".

50. CIAT-OIT and Ministerio de Trabajo y Seguridad Social, El empleo precario en Argentina. 
precarious work for the first time to the English readership. ${ }^{\text {II }}$ The volume was the result of a seminar jointly organized by the International Institute of Labour Studies, an ILO research facility in Geneva, and the Free University of Brussels. Gerry Rodgers, a development economist at the ILO, conceptualized as precarious jobs "with a short time horizon or for which the risk of job loss is high"; for the same reason, irregular jobs were also considered to be precarious. Job precariousness, in his view, involved "instability, lack of protection, insecurity and social and economic vulnerability".52

Since the mid-r980s, comparative studies on labour law exploring the changes in labour contracts and labour legislation in a West-East perspective have increased, revealing well before 1989 a shared concern across the Iron Curtain regarding the new hiring and dismissal practices developed in the capitalist West as well as in the communist East. ${ }^{53}$ Although the topic of precarious work was not explicitly addressed, the spread of flexible contracts, ${ }^{54}$ the changing regulations on dismissals and, more broadly, labour law deregulation were dealt with, indicating the early concern of labour law scholars concerning the possible dismantling of the standard employment model. 55 The major changes that occurred in the Soviet labour market under perestroika were discussed immediately after the fall of the Berlin Wall under the ILO umbrella, which, in I990, organized a conference in Moscow entitled "Towards Labour Flexibility and Employment Reform in the USSR". ${ }^{6}$ The new labour legislation promoted in the second half of the 1980 s, together with the potential role of the flexibility paradigm, lay at the heart of the analysis by scholars under the leadership of Guy Standing. Unlike the explanation of precarious work developed with regard to Western Europe and Latin America, where the process of precarization was clearly seen as an effect of the introduction of flexible labour arrangements, the Soviet Union's labour market was regarded as a system that needed to be more flexible. Although the potential spread of precarious work was not a real concern of those scholars, the risk of falling into periods of labour insecurity did emerge in the analyses.

In the I990s, the debate on precarious work became highly polarized. Orthodox economists saw job flexibility as an opportunity and a necessity

51. Rodgers and Rodgers, Precarious Jobs in Labour Market Regulation.

52. Rodgers, "Precarious Work in Western Europe: The State of the Debate", p. 3.

53. Hepple, "Some Problems of Comparing Socialist and Capitalist Systems of Labour Law"; Ivanov, "Hiring and Dismissal Under Soviet Labour Law".

54. Meulders and Tytgat, "Atypical Employment in EEC Countries"; Boudier, "New Forms of Employment".

55. Wedderburn, "Deregulation and Labour Law in Britain and Western Europe"; Evans and Lewis, "Deregulating Labour Markets and Industrial Relations".

56. Standing, In Search of Flexibility. 
in order to create new employment, usually avoiding the very concept of precariousness. This position was fully endorsed by the European Employment Strategy launched in 1997. ${ }^{57}$ An increasing number of sociologists, however, started emphasizing the close connection between job flexibility and precariousness, explicitly using the term. French socioeconomic scientists were the first to further elaborate on job precariousness, adopting the concept of précarité extensively. ${ }^{58}$ Robert Castel, in his book Les métamorphoses de la question sociale, addressed precariousness as a destabilizing force for society as a whole. ${ }^{59}$ Along the same lines, Serge Paugam and Pierre Bourdieu elaborated on the impact of job precariousness at the social level, in the wake of the hegemony of the flexibility paradigm. ${ }^{60}$ Luc Boltanski and Ève Chiappello, in their well-known book Le nouvel esprit du capitalisme, looked at the spread of precarious work as an effect of the increasing labour market segmentation and the major changes that had occurred in the capitalist system since the crisis of the 1970 . ${ }^{61}$

Since the late I990s, more and more studies in Western countries have explicitly addressed precariousness as the social and individual costs of labour flexibility. ${ }^{62}$ Books such as Richard Sennett's The Corrosion of Characters or Luciano Gallino's Il costo umano della flessibilità are clear examples of this approach. ${ }^{63}$ In Italy, the i 970 debate was not followed by any significant studies until the second half of the 1990 s, ${ }^{64}$ when several scholars such as Andrea Tiddi, Roberto Rizza, and Federico Chicchi started adopting the category of precariousness and precarious work as key concepts in their analyses. ${ }^{65}$ In the United Kingdom, the studies on precarious work in the I990s were fewer and more limited in scope, usually adopting key words such as "insecurity" and "vulnerability" instead of precariousness as such. ${ }^{66}$ The most relevant comparative study of the I990s, the so-

57. For an overview of the flexibility model as a positive employment strategy, see: European Commission, Flexibility and Competitiveness.

58. Lévy, Vivre au minimum; Offe and Deken, "La précarité sur le marché du travail".

59. Castel, Les métamorphoses de la question sociale.

60. Barbier and Nadel, La flexibilité du travail et de l'emploi; Paugam, Le salarié de la précarité; Bourdieu, "La précarité est aujourd'hui partout".

61. Boltanski and Chiapello, Le nouvel esprit du capitalisme.

62. Nätti, "Temporary Employment in the Nordic Countries"; Bruegel and Hegewisch, "Flexibilization and Part-Time Work in Europe"; De Grip, Hoevenberg, and Willems, "Atypical Employment in the European Union"; Standing, Global Labour Flexibility.

63. Sennett, The Corrosion of Character; Gallino, Il costo umano della flessibilità.

64. Exceptions could be found in: Garibaldo, Flessibile o marginali?; Accornero et al., Il lavoro possibile.

65. Rizza, Politiche del lavoro e nuove forme di precarizzazione del lavoro; Tiddi, Precari; Chicchi, Derive sociali.

66. Gallie, Crompton and Purcell, Changing Forms of Employment; Heery and Salmon, The Insecurity Workforce; for a comprehensive overview of job insecurity literature: Sverke, Hellgren, and Näswall, Job Insecurity. 


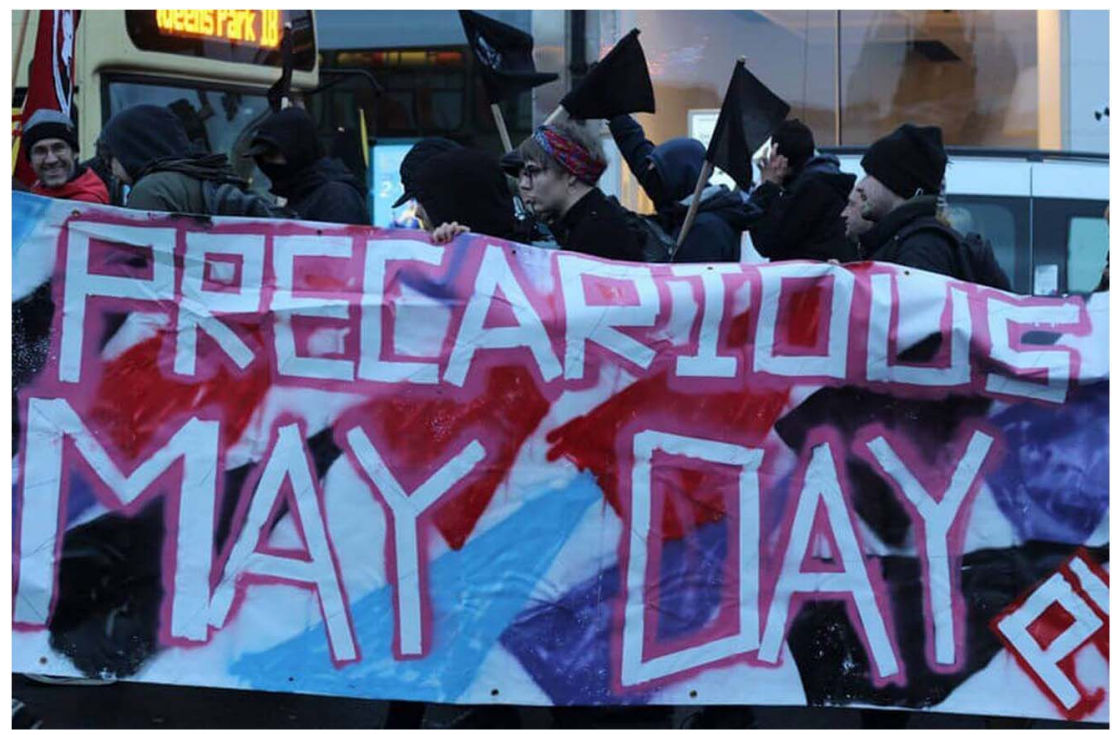

Figure 2. "Precarious Mayday" Demonstration, Brighton May I, 2017.

Photograph by Callum Cant at PoliticalCritique.org, available at https://blog.p2pfoundation. net/precarious-couriers-are-leading-the-struggle-against-platform-capitalism/20I $7 / 08 / 24$

called Supiot Report, written by an interdisciplinary group of experts established under the patronage of the European Commission, also analysed the changes occurring in the European labour laws with a specific focus on the consequences of the spread of flexible labour arrangements. ${ }^{67}$ Several studies investigated the process of precarization in conjunction with the spread of job flexibility also in non-European Western countries such as Canada and Australia. ${ }^{68} \mathrm{Few}$ of them dealt with non-Western countries, and if they did, then again it was mainly with Latin America. ${ }^{69}$

Since the early 2000s, the academic debate on job precariousness has become topical, involving a larger number of scholars in the socioeconomic sciences and humanities all over the Western countries and beyond. In addition to economists, sociologists, and legal experts, anthropologists, psychologists, gender scholars, and political scientists became increasingly involved in the analysis of precarious work, together with

67. Supiot, Au-delà de l'emploi.

68. For an overview of the I990s Canadian debate, see: Cranford, Vosko, and Zukewich, "Precarious Employment in the Canadian Labour Market"; on precarious work in Australia: Burgess and Campbell, "The Nature and Dimensions of Precarious Employment".

69. On Latin America see, for instance: Peñalba and Rofman, Desempleo structural, pobreza y precariedad. 
scholars in the humanities, who discovered a wide range of artistic, literary, and cinematographic products based on the topic. ${ }^{70} \mathrm{~A}$ real iconography of precarity ${ }^{7 \mathrm{I}}$ depicting precarious workers as a proper group, often with recognizable features, evolved, along with studies addressing precarious workers as the core workforce of the knowledge/digital society of twentyfirst-century capitalism. ${ }^{72}$ It is not surprising, then, that more than a dozen special issues devoted to precarious work and precarity at large have been published over the past decade, across a wide range of academic journals, ranging from sociology, to feminist studies, labour law, management studies, social movements studies, drama and art studies, and history. ${ }^{73}$

With the launch of the Italian Mayday parade (200I) and later on EuroMayDay (2005) - the transnational protest promoted by precarious (and migrant) workers on May Day - an increasing number of studies started analysing precarious workers' mobilization in Western Europe, especially in the Mediterranean countries, where protest levels were higher. ${ }^{74}$ Due to

70. For a critical analysis of literary and artistic products dealing with precarity, see, for instance: Contarini, Jansen, and Ricciardi, Le culture del precariato; De Sario, Precari su Marte; IwataWeickgenannt and Rosenbaum, Visions of Precarity; Garrett and Jackson, "Art, Labour and Precarity in the Age of Veneer Politics".

7I. On the representation of precarity: Bruni and Selmi, "Da san Precario a WonderQueer".

72. Among the most recent studies on precarious work, knowledge society and the digital economy, see: Cocco and Szaniecki, Creative Capitalism; Curtin and Sanson, Precarious Creativity; Huws, Labor in the Global Digital Economy; Berardi, And: Phenomenology of the End; Dyer-Witheford, Cyber-Proletariat.

73. The main special issues in the social sciences and humanities devoted to precarious work: Neilsen and Rossiter, "Precarious Labour" The Fibreculture Journal, s (2005); Nienhueser, “Flexible Work - Atypical Work - Precarious Work?', Management Revue, i6 (2005); Bellavitis and Piccone Stella, "Flessibili/Precarie", Genesis, 7, I-2 (2008); De Simone and Scarponi, "Genere, lavori precari, occupazione instabile", Lavoro e diritto, 24:3 (2010); Choudry and Collombat, "Nouvelles voix sur la précarité du travail”, Labour, Capital and Society, 45:I (201 2); Appelbaum, "Precarious Work in Polarizing Times", Work and Occupations, 39:4 (201 2); ILO, "Meeting the Challenge of Precarious Work. A Worker's Agenda", International Journal of Labour Research, 5:I (2013); Kalleberg and Hewison, "Precarious Work in East Asia", American Behavioral Scientist, 57:3 (2013); Hewison and Kalleberg, "Precarious Work in South and Southeast Asia", American Behavioral Scientist, 57:4 (2013); "Precarious Work and Human Rights", Comparative Labor Law and Policy Journal, 34 (2012); "Precarious Situations: Race, Gender, Globality", Women E Performance: A Journal of Feminist Theory, 23:2 (2013); "Youth and Precarious Work", Social Alternatives, 34:4 (2015); "Precarious Work and the Struggle for Living Wages", Alternatives Routes, 27 (2016); Mosoetsa, Stillerman and Tilly, "Precarious Labor in Global Perspective", International Labour and Working-Class History, 89 (2016). Although not formally devoted to precarious work, the following deal extensively with the topic: "Italian Feminisms", Feminist Review, 87:3 (2007); "Globalization and Labor Flexibility: The Latin American Case(s)", Latin American Perspectives, 3 1:4 (2004); Kalleberg and Vallas, Precarious Work; Schierup and Jørgensen, "Politics of Precarity", Critical Sociology, 42 (2016).

74. On Mayday, EuroMayDay and precarious worker's mobilization: Tari and Vanni, "On the Life and Deeds of San Precario"; Neilson and Rossiter, "From Precarity to Precariousness and Back Again”; Choi, Mattoni, "The Contentious Field of Precarious Work in Italy”; Murgia and 
the expansion of the European social movements' campaign against precarious work and the subsequent involvement of European and even international trade union federations - e.g. the International Metalworkers' Federation (IMF) and the European Federation of Food, Agriculture and Tourism Trade Unions (EFFAT) - in the mid-2000s, the concepts of precariousness/precarity/precarious became popular not only within academia, but also in the general public debate. ${ }^{75}$ It is worth mentioning that several academic studies were indeed conducted by scholars belonging to the génération précaire, who combined political commitments towards a condition they themselves were experiencing with the necessary scientific skills to contribute substantially to the study of the topic in a variety of disciplines. $^{76}$

An important part of the European debate from the early 2000 s until the onset of the economic crisis of 2008 focused on the conceptualization and implementation of the so-called flexicurity model, based on the idea of merging managerial flexibility and employment security. This debate was at first led by Scandinavian scholars ${ }^{77}$ and acquired a European scope when flexicurity was adopted as an explicit goal in the renewal of the European Employment Strategy. ${ }^{78}$ In this debate, however, critical approaches also emerged, as flexibility was considered to be a possible driver for a new wave of precarization on the global scale. ${ }^{79}$ Scholars such as Ruud Muffels, Peter Auer, and Frank Tros pointed out the difficulty in balancing employment instability with highly diverse systems of social security that were based on

Selmi, "Inspire and Conspire. Italian Precarious Workers"; Marchart, Die Prekarisierungsgesellschaft, in particular ch. 4 (pp. I89-230); Foti, "The Precariat for Itself"; Fumagalli, "Cognitive Relational (Creative) Labor”; Bodnar, "Taking it to the Streets”.

75. For campaigns of international unions on precarious work, see: International Metalworkers' Federation (IMF), Precarious Work Affects Us All; European Federation of Food, Agriculture and Tourism Trade Unions (EFFAT), Precarious Work in Europe; EFFAT, Social Justice from Farm to Fork; ACTRAV, From Precarious Work to Decent Work; for a critical analysis of unions' response to precarious work: Keune, "Trade Union Responses to Precarious Work in Seven European Countries”; Knotter, “Justice for Janitors Goes Dutch”.

76. Among the studies made by and dealing with the génération précaire: Murgia and Ermano, Mappe della precarietà; Armano, Bove and Murgia, Mapping Precariousness, Labour Insecurity and Uncertain Livelihoods; Busch, Jeskow and Stutz, Zwischen Prekarisierung und Protest.

77. Wilthagen, "Flexicurity: A New Paradigm"; Wilthagen and Rogowski; “The Legal Regulation of Transitional Labour Markets"; Madsen, "The Danish Model of Flexicurity".

78. Among official documents and responses: European Commission, Modernising Labour Law; European Commission, Towards Common Principles of Flexicurity; European Trade Union Confederation (ETUC), "The Flexicurity Debate and the Challenges for the Trade Union Movement"; European Foundation for the Improvement of Working and Living Conditions, "Varieties of Flexicurity"; on flexicurity as a positive model: Wilthagen, Flexicurity Practices; Auer, "In Search of Optimal Labour Market Institutions"; Cazes and Nesporova, Flexicurity. 79. Muffels, Flexibility and Employment Security; Berton, Richiardi and Sacchi, Flex-insecurity; Possenti, Flessibilità. 
the differing financial capabilities of European states. This was increasingly discussed from $2007 / 2008$ onwards, when critical studies on the financial sustainability of the flexicurity model were published. ${ }^{80}$ In the 2010 s, in addition to the ILO's the and EU's studies, ${ }^{81}$ Romke van der Veen, Mara Yerkes, and Peter Achterberg's research, as well as Toomas Kotkas's and Kenneth Veitch's study, address the relationship between welfare regimes, labour market flexibility, and job precariousness at large, advocating a new basic floor of social rights. ${ }^{82}$

\section{GENDERING AND GLOBALIZING PRECARIOUS WORK IN TWENTY-FIRST-CENTURY CAPITALISM}

\section{Women's history and feminist scholarship}

The literature on precarious work became much more global and gendered in the new millennium, overcoming the Eurocentric perspective and the gender blind approach of the debate in the I980s and I990s. In 2010, the European Parliament approved a resolution on "precarious women workers", which stated that the "gender nature of precarious work" and gender discrimination underlie the prevailing spread of job precariousness. ${ }^{8}$ The relationship between gender and precarious work has been analysed with increasing attention since the 2000 s, even though, in some countries, the feminization of atypical contracts has been studied continuously since the

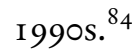

In the new millennium, several scholars, adopting the category of gender and intersectionality, have framed precarious work in the history of (gendered) capitalistic relations of production. For example, Angela Mitropoulos's essay of 2005 and Leah Vosko's study published in 2000 criticized the novelty of the phenomenon from a feminist point of view. ${ }^{85}$ Andrea Komlosy explicitly links the analysis of capitalism, labour relations, and precarious work. In questioning wage labour as the dominant labour

80. On flexicurity in the crisis years: Auer, "What's in a Ne"; Andersen, Lubanski and Pedersen, The Competitiveness of the Nordic Countries; Tros, "Flexicurity in Europe"; Heyes, "Flexicurity in Crisis"; De Vos, "European Flexicurity and Globalization".

81. European Commission, DG Employment, Social Affairs and Equal Opportunities, Study on Precarious Work and Social Rights; ILO, "Meeting the Challenge of Precarious Work. A Worker's Agenda".

82. Kotkas and Veitch, Social Rights in the Welfare State; Van der Veen, Yerkes, and Achterberg, The Transformation of Solidarity.

83. European Parliament, Resolution of 19 October 2010 on Precarious Women Workers, I9 October 2010 (n. 2010/2018).

84. On Italy, see for instance: Altieri, “'New economy', lavori 'atipici' e conseguenze di genere”; CENSIS, L'impatto della flessibilità sui percorsi di carriera delle donne. On Latin America: Lindenboim, "The Precariousness of Argentine Labor Relations".

85. Mitropoulos, "Precari-Us?”; Vosko, Temporary Work. 
relationship of historical and contemporary capitalism, she conceived precarious work as a labour relationship by itself, which has characterized the capitalist system throughout its history. ${ }^{86}$ The concept of intersectionality, introduced in the early I 990 s by Kimberlé W. Crenshaw, ${ }^{87}$ has proven to be relevant not only for feminist scholarship, gender studies, and women's history, ${ }^{88}$ but also for labour history. ${ }^{89}$ Addressing the intersection of gender, class, race, ethnicity (and citizenship) in analysing precarious workers and recurring forms of job precariousness seems indeed particularly relevant, as shown, for instance, by Annette Thörnquist and ÅsaKarin Engstrand's study on precarious work in Sweden. ${ }^{90}$

Eileen Boris stresses that single women, African Americans, migrants, and domestic and agricultural workers were never fully integrated in the steady employment codified in the United States by the New Deal. ${ }^{1 \mathrm{I}}$ Along the same lines, Sean Hill has recently analysed precarity in its relationship with the political and theoretical conceptualization of "Black Lives Matter", launched by the homonymous movement in 20I3. By emphasizing how black Americans experienced precariousness well before the rise of neoliberalism, Hill openly contests Standing's concept of the precariat as a new class, claiming that black Americans have been part of a possibly "eternal precariat"..$^{2}$

Drawing from Butler's theory, Isabelle Lorey points out that the allegedly new neoliberal precarity has a long tradition in industrial capitalism, which has excluded women and migrants from social security provisions also in Western countries. ${ }^{93}$ The article by Saffia Elisa Shaukat on Italian seasonal workers in Switzerland clearly illustrates how job precariousness has characterized the working and living conditions of Italians who have emigrated beyond the Alps since the I950s. ${ }^{94}$ My own studies on Italian women workers over the past sixty years have shown to what extent the sexual division of labour and sex-based discrimination have been at the heart of the gendered nature of precarious work, which has characterized women's working conditions in all economic sectors in both industrial and postindustrial societies. ${ }^{95}$ Additional studies on North America have revealed the existence and relevance of temporary employees, labelled "Kelly Girls" for

86. Komlosy, "Work and Labour Relations".

87. Crenshaw, Mapping the Margins.

88. For a history of the concept of intersectionality and feminist scholarship critique: Cooper, "Intersectionality".

89. See, for instance, Boris and Janssens, "Complicating Categories".

90. Thörnquist, Engstrand, Precarious Employment in Perspective.

91. Boris and Dodson, "Working at Living".

92. Hill, "Precariy in the Era of \#BlackLivesMatter".

93. Lorey, State of Insecurity; Puar, "Precarity Talk".

94. Shaukat, "Emigrer et travailler en Valais".

95. Betti, Women's Working Conditions and Job Precariousness. 
being mostly female, in the Canadian and US labour markets in the I950s and I960s. Part of the so-called temporary help industry, those women experienced working conditions that would today be labelled precarious, as Leah Vosko's and Erin Hatton's studies have suggested. ${ }^{6}$

In Mediterranean countries, feminist scholars such as Adriana Nannicini, Cristina Morini, Silvia Federici, and Laura Fantone ${ }^{97}$ have contributed to revealing the gendered transformation of the capitalist system in the socalled neoliberal age, which increased the level of precariousness in women's working and living conditions. Women's activism against precariousness has been dealt with in regard to Italy and Spain, where specific feminist groups such as Precarias a la Deriva were formed, becoming themselves a subject of investigation for feminist scholars..$^{98}$ In addition to Spanish and Italian feminists, German feminist scholars have contributed to addressing the relationship between precariousness, freedom, and self-determination. ${ }^{99}$ The nexus of reproduction and job precariousness has been dealt with at various levels, mostly concerning the Global North. ${ }^{100}$

A virtual round table coordinated by Jasmine Puar shows the diverse possible conceptualizations of precariousness and precarization in the feminist milieu. In addition to the economic aspect, feminist thinkers address the existential dimension by examining the relationship between precarity and the female body, precarity and reproduction, as well as the various precarious identities. ${ }^{\mathrm{O}}{ }^{\mathrm{I}}$ Feminae Precariae is the definition recently proposed by Alyson Cole and Victoria Hattam to understand the gendered precarization of neoliberal capitalism, explored from several perspectives in the 2017 Fall/Winter issue of Women's Studies Quarterly. ${ }^{\text {I02 }}$ In Cole and Hattam's view, "the feminine form highlights the gendered fragmentation of production, reproduction, and citizenship; the plural conjugation signifies how precarization, which is embedded in the project of increasing individual capital, is widespread and yet undermines collectivism". ${ }^{\text {103 }}$

96. Vosko, Temporary Work; Hatton, The Temp Economy.

97. On feminist perspectives on precarious work: Nannicini, Le parole per farlo; Fantone, "Precarious Changes"; Fantone, Genere e precarietà; Morini, Per amore o per forza; Federici, "Precarious Labor".

98. Precarias a la Deriva, A la deriva por los circuitos de la precariedad femenina; Casas-Cortés, "A Genealogy of Precarity"; Fantone, "Precarious Changes"; Di Cori, "Comparing Different Generations of Feminists”.

99. Fink et al., Prekarität und Freibeit?; Aulenbacher, Riegraf, and Völker, Feministische Kapitalismuskritik, in particular ch. 9, "Phänomene der Prekarisierung: Entsicherung und erschöpfte Arbeits- und Lebensarrangements", pp. I $26-\mathrm{I}_{3} 8$.

I00. See, for instance: Chan and Tweedie, "Precarious Work and Reproductive Insecurity".

IоI. Puar, "Precarity Talk".

I02. Although not explicitly devoted to precarity, this issue if WSQ addresses the topic in several articles.

I03. Cole and Hattam, "What Works?". 
In the crisis years, the books edited by Judy Fudge and Rosemary Owen ${ }^{104}$ and Leah Vosko ${ }^{105}$ focused on the gendered nature of precarious work and the growing percentages of precariousness among women, questioning eventually the alleged positive relationship between the feminization and flexibilization of work at the global level. By analysing the relationship between precarious work and changing legal norms, Fudge and Owen establish to what extent national laws and policies had historically reinforced gender roles, according to which women, when they worked, were usually employed temporarily in more unstable and precarious jobs. Vosko shows how the erosion of the standard employment model did not help to reduce the gender inequalities in the labour market or women's level of precariousness, and she advocates a new employment relationship.

Some feminist scholars adopting a Global South perspective also provided a crucial contribution towards understanding the relationship between the current wave of precarization and the global feminization of labour, commonly understood as the increase of women's participation in paid work worldwide but also as the extension of traditional female working conditions to the workforce as a whole. ${ }^{106}$ Fatima El-Tayeb points out that precarity is not a symptom of a crisis of late capitalism, but rather a long-term structural element of the modern capitalist system, stressing how populations outside the West had been the main subjects of a process of precarization. ${ }^{107}$ Encarnacion Gutiérrez-Rodríguez and Nicole Constable deal with the relationship between precariousness, feminization of work and migration, something which several scholars have contributed to developing in regard to specific sectors, such as domestic and care work, call centres, and farm work. ${ }^{\text {Io8 }}$

Women's history and feminist scholarship have provided a crucial contribution to understanding precarization as a continuous process and precariousness as a defining condition of women's employment in the long run, something underlined also by the few studies taking into account the early modern era. The special issue Flessibili/Precarie (Flexible/Precarious) of the Italian women's history journal Genesis revealed how precarious and flexible work could be conceptualized also in the pre-industrial era with regard to several feminized sectors. ${ }^{109}$

104. Fudge and Owen, Precarious Work: Women and the New Economy.

I05. Vosko, Managing the Margin.

I06. Mitropoulos, "Precari-Us?"; Lorey, State of Insecurity.

I07. El-Tayeb, "Making Do. Survival Strategies under Precarity".

I08. Gutiérrez-Rodríguez, Migration, Domestic Work and Affect; Gutiérrez-Rodríguez, "The Precarity of Feminisation"; Constable, "Migrant Motherhood, 'Failed Migration'”; Alves de Matos, "Gender Commodification and Precarity"; Mayer-Ahuja, "Three Worlds of Cleaning"; Hobson and Bede, "Precariousness and Capabilities".

I09. Bellavitis and Piccone Stella; Atypical Works in Pre-Industrial Europe. Pluriactivity, Mobility and Social Identities; Canepari and Ragnard, "Abitare la città". 
Research on industrial homeworking is particularly relevant for understanding the persistence of specific forms of traditionally highly feminized precarious work, usually closely connected with informal and undocumented work. ${ }^{\text {IO }}$ Since 1997, women's informal work has been addressed also by the global research-policy-action network Women in Informal Employment Globalizing and Organizing (WIEGO), which has contributed to expand the knowledge of the quantity and quality of informal work worldwide with a specific focus on feminized highly precarious groups of workers (home-based workers, street vendors, domestic workers, waste pickers). The relationship between informal and precarious employment has been addressed, within the wider debate on the quality of employment. ${ }^{\text {III }}$

Another relevant contribution has come from the studies on mobility and pluriactivity, which have revealed the multiple strategies adopted by male and female "contingent", "casual", or "seasonal" workers to face their structural conditions of job and life precariousness. How job precariousness has historically shaped not only male and female behaviour, but also the households' social and economic strategies and their gender division of labour is particularly relevant in a diachronic perspective. Late nineteenth- and early twentieth-century proletarian and sub-proletarian families, studied by Ad Knotter, ${ }^{\mathrm{II} 2}$ can be compared to the twenty-first century precarious ones, both in the Global North and in the Global South. ${ }^{\text {I3 }}$

\section{Transnational studies and perspectives from the Global South}

The onset of the global economic crisis in 2008 played a relevant role in popularizing and globalizing the precarious work debate. ${ }^{\text {II } 4}$ The relationship between precariousness and globalization became one of the main strands of research during the crisis years, ${ }^{115}$ also thanks to the role of the ILO, the Eurofound, and the European Commission, which funded several transnational research projects and conferences on this topic. ${ }^{16}$ A special

I Io. Prugl, Global Construction of Gender; Boris and Prugl, Homeworkers in Global Perspective. I II. See, among others: Chen, "The Informal Economy"; Carré, Negrete, Vanek, "Relating Quality of Employment to Informal Employment"; on informality, poverty and precariousness from a gender perspective, see also: Kudva, Beneria, Rethinking Informalization.

I I 2. Knotter, "Poverty and the Family-Income Cycle".

II3. On twenty-first century precarious family: Salmieri, "Job Inseccurity, Flexibility and Home-Work Balance”.

I I4. Among the most recent comprehensive studies, see, for instance: Kalleberg and Vallas, Precarious Work; Meehan and Strauss, Precarious Worlds; on Western countries, see: Sargeant and Ori, Vulnerable Workers and Precarious Working.

I I s. Thornley, Jefferys, and Appay, Globalisation and Precarious Forms of Production and Employment; Ross, Nice Work if You Can Get It; for a review of the main studies: Kalleberg, "Globalization and Precarious Work".

i i6. Broughton and Biletta Kullander, Flexible Forms of Work; Evans and Gibb, Moving from Precarious Employment to Decent Work; European Commission, DG Employment, Social Affairs 
issue of the ILO's International Journal of Labour Research featured some of the contributions to a 20I I symposium, held by the ILO's Bureau for Workers' Activities (ACTRAV), entitled Meeting the Challenge of Precarious Work: A Workers' Agenda. ${ }^{17}$ The articles addressed the relationship between precarious work and the ILO's standards, including the 2008 "Declaration on Social Justice for a Fair Globalization" and the 2015 Recommendation concerning the "Transition from the Informal to the Formal Economy". The ILO's role in establishing stable employment relationships across the globe up to the crisis of the I970s is explored, along with the current need for new standards to protect precarious workers in the twenty-first century. ${ }^{118}$ In 2016 , the ILO issued the report Non-Standard Employment around the World, after hosting a tripartite meeting on the same topic in 20I5. The effort to increase the knowledge about the impact of "non-standard employment" worldwide was part of the "Future of Work Centenary Strategy" launched by the DirectorGeneral. Although the concept of precariousness was mentioned, "nonstandard employment" was preferred to emphasize the decent work deficits as well as the main areas of insecurity experienced by workers in nonstandard employment, which should be addressed by policies ${ }^{119}$. The relationship between precarious work and human rights has become another relevant topic in the international debate on precarization and globalization, which has also seen the involvement of international trade union federations. ${ }^{\mathrm{I} O}$

In the crisis years, precarious work also became a relevant issue in the former Communist countries. Eastern Europe has been included in recent comparative studies with a European scope, while research projects funded by the EU, such as "Precarious Work and Social Rights" and "PRECARIR", included or were about Eastern Europe, too. ${ }^{\text {I2I }}$ Additional studies have been published also in regard to Russia and former Yugoslavia. ${ }^{\mathrm{I} 22}$ In the latter, precarious work is often related to the restructuring of the industrial system during the transition from planned to market economies,

and Equal Opportunities, Study on Precarious Work and Social Rights; Trif, Koukiadaki, and Kahancová, The Rise of the Dual Labour Market; Keune, Bargaining for Social Rights.

I I7. ILO, "Meeting the Challenge of Precarious Work: A Workers' Agenda", International Journal of Labour Research, 5:1: Special Issue (2013).

I I 8. Demaret, "Editorial: ILO Standards and Precarious Work"; Marín, "Precarious Work".

I 19. ILO, Non-Standard Employment around the World.

I 20. On precarious work and human righsts: IUF, "Precarious Work: Undermining Human Rights"; the special issue: "Precarious Work and Human Rights", and in particular: Mantouvalou, "Human Rights For Precarious Workers"

I 2 I. European Commission, DG Employment, Social Affairs and Equal Opportunities, Study on Precarious Work and Social Rights.

I 22. On precarious work in Eastern Europe and Russia: Herrmann, Bobkov, and Csoba, Labour Market and Precarity of Employment; Walker, "Stability and Precarity". 
which frequently led to a process of deindustrialization, as Chiara Bonfiglioli's studies show. ${ }^{\mathrm{I} 3}$ The privatization and closure of previously stateowned enterprises has led, according to these studies, to a generalized process of precarization and informalization. ${ }^{\text {I24 }}$

In addition to covering former communist Eastern European countries, an increasing number of studies have addressed the informalization and precarization of working conditions in twenty-first-century China, at times comparing contemporary labour relations to the ones existing in Mao's era when the "iron rice bowl" model granted job stability to the Chinese workers in the massive state sectors. ${ }^{\text {I25 }}$ Other studies investigate the changes that occurred between the mid-I980s and the mid-r990s in Chinese labour law and employment policies, which led to the rise of temporary staffing agencies as a solution to regional unemployment. The key role of those agencies in making the labour market more flexible and increasing the level of Chinese labour force precarization is discussed by Feng Xu, who points out how flexible employment in China is linked more to informal labour arrangements than in Western countries. ${ }^{26}$ Thanks to the work of Heidi Gottfried and Anne Allison, the breakdown of the post-war system of employment stability and the increasing spread of precarious work in post-I99I Japan have also been addressed, revealing a rather similar path to that of Western Europe and North America. ${ }^{\mathrm{I} 27}$ Precarious labour in contemporary Japan, according to Allison, has reshaped social relations and increased the sense of loss and insecurity compared to the steadiness of the previous family-corporate system. ${ }^{\text {I28 }}$

Asia at large, Africa, and Latin America entered the debate on precarious work in the crisis years, fuelled by Guy Standing's controversial book, The Precariat. ${ }^{\mathrm{I} 29}$ The debate saw the involvement of a number of scholars working in the Global South or conducting research on it. Among them, Ronaldo Munck contested the novelty and relevance of Standing's concept of the precariat, providing an interesting contribution to understanding the role of precarious work in the history of capitalism beyond Western countries. ${ }^{130} \mathrm{He}$ stressed the relevance of the informality debate and

I23. Bonfiglioli, "Gender, Labour and Precarity".

I24. See, in addition: Woolfson, "Pushing the Envelope".

I 25. On precarious and informal work in China: Kuruville, Lee and Gallagher, From Iron Rice Bowl to Informalization; Zhou, "The State of Precarious Work in China"; Zhang, "From China to the Big Top"; Swider, Building China.

I26. Xu, "Temporary Work in China".

I27. On precarious work in Japan: Allison, “Ordinary Refugees”; idem, Precarious Japan; Gottfried, "Precarious Work in Japan”; Piotrowski, Kalleberg and Rindfuss, "Contingent Work Rising”.

I 28. On loss and precarity, see also: Rachwał, Precarity and Loss.

I29. Standing, The Precariat.

I30. Munck, "The Precariat: A View from the South". 
informal work to understand the historical and contemporary forms of labour precariousness in the Global South, where Fordism and the standard employment model had never been the norm.

However, the discussion on the informalization of labour relations as a global process has a longer tradition, dating back to the I990s. ${ }^{13 \mathrm{I}}$ Ulrich Beck coined the expression "Brazilianization of the West" at the end of the I 990 s to stress the informalization of Western labour conditions and the unexpected convergence with informal/precarious labour arrangements already existing in the peripheral economies of the Global South, ${ }^{132}$ something he had already envisaged to some extent in his study on the Risikogesellschaft in 1986. ${ }^{133}$ In the early 20 Ios, Jan Breman and Marcel van der Linden corroborated the idea of a convergence of Western countries and the Global South insofar as the spread of informality and precarity was concerned, claiming that the "West is more likely to follow the Rest than the other way around". ${ }^{134}$ Along the same line, Andreas Eckert has claimed that a process of convergence between the Western and African labour arrangements has occurred in the light of the normalization of precarity in the West. ${ }^{\text {I5 }}$ Sara Mosoetsa, Joel Stillermann, and Chris Tilly - in their introduction to the special issue of International Labor and Working-Class History devoted to "Precarious Labor in Global Perspective" - argue for a global convergence in labour relations as well, interpreting the recent spread of precarious work as a "return". ${ }^{136}$

Scholars adopting a Global South and post-colonial perspective have emphasized the need to connect the debate on the informalization of labour ${ }^{137}$ with the discourse on job precariousness to fully grasp the normality of precarious work outside Western countries in a synchronic and diachronic perspective. The relationship between precarization and informalization has become a crucial driver in expanding the precarious work debate in the Global South as a whole in the 20 IOs. $^{138}{ }^{8}$ Several scholars have

\section{3 I. Beck, The Brave New World of Work.}

I32. On the concept of peripheral economy and labour, see, for instance: Amin and Van der Linden, "Peripheral Labour”; Dennis and Pickles, "Global Work, Surplus Labor".

I33. Beck, Risikogesellschaft. Auf dem Weg in eine andere Moderne.

I 34. Breman and Van Der Linden, "Informalizing the Economy", p. 920.

I35. Eckert, "Capitalism and Labour in Sub-Saharan Africa".

I 36. Mosoetsa, Stillerman, and Tilly, "Precarious Labor in Global Perspective".

I37. On the informalization of work in the Global South: Breman, Circulation and Informalization of the Workforce; Chang, "Informalising Labour in Asia's Global Factory"; on informal workers, see also: Bhattacharya and Lucassen, Workers in the Informal Sector; Eckert, Global Histories of Work; Rogan et al., "Informal Employment in the Global South".

I 38 . On the nexus of precarious and informal labour in the Global South and peripheral economies: Barchiesi, "Informality and Casualization as Challenges"; Theron, "Informalization from Above, Informalization from Below; Petrungaro, "The Fluid Boundaries of "Work"”; Arnold and Bongiovi, "Precarious, Informalizing, and Flexible Work"; Munck, "The Precariat: A View from the South"; Breman and Van Der Linden, "Informalizing the Economy". 


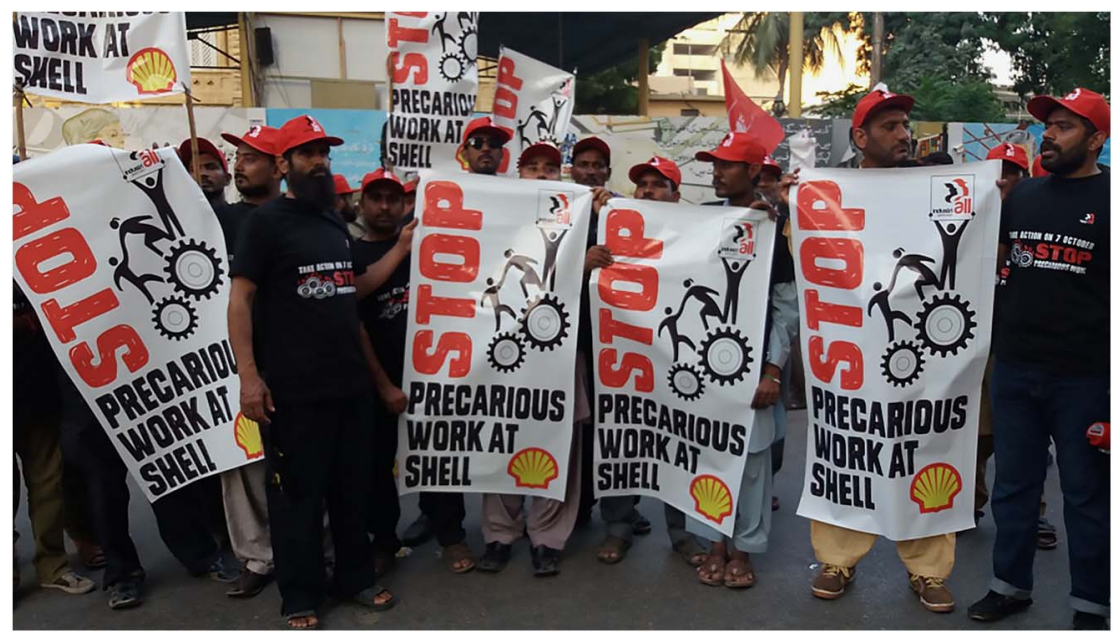

Figure 3. Industriall affiliates in Pakistan, PCEM, demonstrates against Shell in Karachi, October, 72017.

Pakistan Federation of Chemical, Energy, Mine, and General Workers Union-PCEM. Used by permission. Photo available at http://www.industriall-union.org/unions-take-action-againstprecarious-work-at-shell.

claimed, providing empirical evidence for their arguments, that Africa, Latin America, and Asia have experienced worsening labour conditions since the second half of I970s, which had interrupted previous attempts of creating a more formalized and regulated labour market. A new wave of informalization/precarization, according to these studies, started also in the Global South in the late 1970 and early 1980 s. ${ }^{139}$

The levels and forms of precariousness affecting South, South-East, and East Asian labour markets have been addressed by scholars such as Arne Kallenberg and Kevin Hewison, who link the expansion of precarious work in those contexts to the development of global production chains under "neoliberal globalization". Precarious workers are labelled differently from country to country, experiencing a diverse degree of instability in East Asian countries (Taiwan, South Korea, China, and Japan) or in southern and southeastern Asian ones (Indonesia, Thailand, the Philippines, Vietnam, Sri Lanka, and India).$^{\mathrm{I}}{ }^{\circ}$

Jan Breman and Rina Agarwala, in analysing the Indian context, have shown the relevance of addressing the relationship between informal labour

I39. Barchiesi, "Informality and Casualization as Challenges"; CIAT-OIT and Ministerio de Trabajo Y Seguridad Social, El empleo precario en Argentina.

I40. On precarious work in Asia: Kalleberg and Hewison, "Precarious Work and the Challenge for Asia"; Hewison and Kalleberg, "Precarious Work and Flexibilization in South and Southeast Asia”. 
and precarious work, due to the prevailing informality of Indian labour relations in the twentieth century and its increase in the formal economy of the new millennium. The expansion of outsourcing, subcontracting, self-employment, and export-led factories has been fuelled by the neoliberal reforms of the early I990s, according to Agarwala's study on the textile and garment sectors, resulting in the spread of informal and more precarious labour arrangements. ${ }^{\mathrm{II}}$ More recent empirical analysis has provided additional evidence of the features of such a spread and its consequences. ${ }^{\text {I2 }}$

In addition to the Indian context, ${ }^{143}$ an increasing number of studies in English, Spanish, and Portuguese have been investigating precarious work and informal work in the urban economies of twenty-first-century Central and Latin American metropolises. Job and life precariousness appears as intertwined in the life of the urban poor, such as street vendors, waste pickers, sex workers, and other informal workers of Argentina, Brazil, and other countries. ${ }^{\text {I4 }}$ The relationship between urban economies, informality, and precarity has been investigated with regard to different cities in the Global South, ${ }^{145}$ including urban Africa at large. ${ }^{146}$ In addition, urban precarious (and informal) workers - ranging from street vendors to selfemployed workers in the handmaking or creative sectors - have been studied in such cities in the Global North as New York, Detroit, and Milan, revealing to what extent the condition of precariousness could be shared by professionals and the homeless in twenty-first-century capitalist cities. $^{\text {I }}{ }^{4}$

Franco Barchiesi, Carl-Ulrik Schierup, and Bridget Kenny have shown the nexus of precarity and informalization in Apartheid and PostApartheid South Africa, pointing out how the race system influenced the level of stability and precarity in both periods, but also the extent of the more recent wave of informalization/precarization. ${ }^{\mathrm{I}}{ }^{8}$ The latter has also been explored in Southern African countries by Oupa Bodibe, who addresses the phenomenon with regard to Lesotho, Mozambique, South

I4 I. Breman, Footloose Labour; Breman, At Work in the Informal Economy of India; Agarwala, Informal Labor; Agarwala and Chun, "Global Labour Politics in Informal and Precarious Jobs". I42. Sapkal and Shyam Sundar, "Determinants Of Precarious Employment In India".

I43. Shankar and Sahni, "The Inheritance of Precarious Labor".

I44. On precarious work in Latin America: Millar, “The Precarious Present”; Burchielli, Delaney, and Goren, "Garment Homework in Argentina".

I45. Das and Randeria, "Politics of the Urban Poor".

I46. Tranberg Hansen and Vaa, Reconsidering Informality; Webster, Britwum, Bhowmik, Crossing the Divide;

I47. Gerrard, Precarious Enterprise; Dawkins, "Do-It-Yourself"; De Peuter, "Confronting Precarity in the Warhol Economy"; Styhre, Precarious Professional Work; for a more general overview of informal work in developed countries: Boels, The Informal Economy.

148. Barchiesi, Precarious Liberation; Schierup, Under the Rainbow; Kenny, The Regime of Contract in South African Retailing 
Africa, Swaziland, Zambia, and Zimbabwe, stressing the role of multinational companies. ${ }^{49}$

Other studies have recently noted the relevance of connecting precarious work and the free/unfree labour debate. ${ }^{\text {Iso }}$ Christian De Vito's research on colonial and post-colonial Latin and Central America suggests addressing the relationship between precarity and workers' control to understand how the different degrees of precarity could be connected to workers' autonomy. ${ }^{\text {II I }}$ Some studies point out the lack of freedom experienced by some precarious workers, namely migrants and undocumented workers, and the long-existing coexistence of forced labour, exploitation, and precarity up to the contemporary forms of modern slavery. ${ }^{152}$ The intersection of precarity, free/unfree labour, and migration has been analysed as a relevant subject of investigation as well. ${ }^{153}$ Increasingly, studies are looking at the conditions of migrant workers as precarious, underlining the gender implications as well as the racial ones. Among others, Carl-Ulrik Schierup offers new findings to understand the relationship between precarious work and migration at the global level and in the long run. ${ }^{\text {I54 }}$

The historiography on the role of intermediaries in the labour market, moreover, shows how the diverse recruitment methods could contribute to the expansion of precarity and unfree labour conditions as well. ${ }^{155}$ The resurgence of the figure of the gangmaster in the agricultural sector, explicitly and repeatedly banned in the British as well as the Italian contexts, has increased the degree of precariousness of rural workers in the twenty-first century, and they have often been obliged to accept exploitative and unfree labour conditions to hold onto their jobs. ${ }^{156}$ In addition to gangmasters, labour brokers and middlemen in general have played a significant role in increasing the nexus between precarious and unfree labour in the Global South as well as in the Global North. ${ }^{157}$

I49. Bodibe, The Extent and Effects of Casualisation in Southern Africa.

I 0 . Benjamin, "The Persistence of Unfree Labour"; Lima, Freedom, Precariousness, and the Law; Chalhoub, "The Precariousness of Freedom in a Slave Society"; Armstead et al., "And I Poor Slave Yet”.

I 5 I. De Vito, "Labour Flexibility and Labour Precariousness"; for an overview of the debate on precarity and workers' control, see: Ross, "The New Geography of Work"; Trott, "From the Precariat to the Multitude".

I 5. Lewis et al., Precarious Lives; Andrees and Belser, Forced Labor; Bales, Disposable People; Brass, Labour Regime Change in the Twenty-First Century.

I 53. Castles, "Precarious Work, and Rights".

I 54. Schierup and Jørgensen, "Politics of Precarity".

I 55. Bosma, Van Nederveen Meerkerk, and Sarkar, Mediating Labour; Wadauer, Buchner, and Mejstrik, The History of Labour Intermediation.

I 56. On gangmasters in the agricultural sector: Patrick, "Agricultural Gangs in Victorian England"; Leogrande, "Caporalato e nuove schiavitù"; Brass, "Medieval Working Practices?"

I 57. On labour brokering see, for instance: Theron, "Intermediary or Employer?” 


\section{CONCLUSION: HISTORICIZING PRECARIOUS WORK IN GLOBAL CAPITA LISM}

The debate on precarious work in the past forty years has become increasingly interdisciplinary and international, involving all the social sciences and humanities worldwide, including history. This article has shown that precarious work and job precariousness frequently started to be addressed in the nineteenth century and never disappeared altogether from social enquiries and the social sciences literature, including the studies conducted during the Fordist era. A strictly Euro-centric perspective was dominant in the debate until the I990s, leading to the universalization of the Western capitalist model and the adoption of its standard employment relationship as the norm compared to which precarious work was considered an exception (and a novelty). In the new millennium, feminist scholarship and Global South perspectives have contributed to gendering and globalizing the precarious work debate, criticizing Euro-centric approaches. The relevance of allowing for different models of capitalism in the precarious work debate has become apparent, along with the importance of connecting precarious work and informal work to understand precariousness in particular in non-Western countries, but also increasingly in the Global North.

Several strands of research can contribute to a better understanding of the historical role of precarious work in the history of industrial and postindustrial global capitalism. Following the feminist and post-colonial critique, studies deconstructing the meaning of work, usually understood only as wage labour, could be useful to pinpoint the crucial role of other forms of work in the home-based and subsistence economy. Research adopting the categories of gender and intersectionality, as well as Global South perspectives, have played a crucial role in criticizing the mainstream periodization and in rethinking the role of precarity/stability in the history of industrial and post-industrial capitalism beyond Western countries. Studies of the effect of the transition from state socialism to a market economy are particularly useful to understand how the socialist model of stability has been disrupted after the demise of state socialism and how, in the former Communist countries, similar forms of precariousness have developed. Research addressing informalization and precarization as intertwined phenomena could suggest further historical routes, which might provide additional evidence of the key role of precarious workers in the history of global capitalism. Moreover, migration studies are particularly relevant to understand the precarity/freedom/citizenship nexus.

From a conceptual point of view, historicizing precarious work in the history of global capitalism implies acknowledging job stability as an exception and job precariousness as its norm. The concept of "waves of precarization" is relevant for comparing forms of precarity at different times and in various places, but also for mapping the existence of precarious 
workers and their features in different economic sectors over time. The diverse waves of precarization have probably been generated by international macro-economic events (e.g. the capitalist crisis), influenced by global political dynamics (e.g. the bipolar Cold War order and its end), shaped by economic theory (e.g. Keynesianism vs. neoliberalism) and production models (e.g. Fordism vs. post-Fordism), and opposed by labour actions, social movements, and progressive labour laws. ${ }^{58}$ Rereading the history of industrial and post-industrial capitalism through the opposite concepts of stability/precarity enables us to reconstruct not only the development of the working class and its path towards growing levels of stability in Western countries, but also to retrace the changes in the labour conditions of the so-called peripheral/marginal subjects, among them women, migrants, children, and Global South workers as a whole. Comparing the enduring figures of precarious workers in their manifold manifestations (e.g. industrial homeworkers, street vendors, farmhands, domestic and sex workers) could reveal how subsequent waves of precarization have improved or worsened the labour and living conditions of marginalized subjects across the globe and in different periods.

\section{B I B L IO G R A PHY}

\section{Printed sources}

Bоотн, C., Life and Labour of the People in London, 9 vols (London, I 892-1 897).

Buret, E., De la misère des classes laborieuses en France et en Angleterre, 2 vols (Brussels, I 842). DAY, D., "Poverty and Precarity", The Catbolic Worker, 6 (I952), pp. I-4, available at http:// www.catholicworker.org/dorothyday/articles/633.html; last accessed 7 May 2018.

Engels, F., The Condition of the Working Class in England (New York, I 883).

FranchetTi, L. and S. SonNino, La Sicilia nel I876, 2 vols (Florence, i 877).

JACINI, S., Relazione finale sui risultati dell'inchiesta agraria (Rome, I 884).

Mayhew, H., London Labour and the London Poor, 4 vols (London, I 85 I-1 862).

Marx, K. and F. Engels., Manifest der Kommunistischen Partei (London, I 848).

MarX, K., Das Kapital. Kritik der politischen Oekonomie, 3 vols (Hamburg, I867-1 894).

MORRIS, W., Signs of Change (London, I $88_{3}$ ).

PEsEnTI, A., "Sottoretribuzione e miseria", in Commissione parlamentare d'inchiesta sulla miseria in Italia e sui mezzi per combatterla, Problemi economici e sociali della miseria (Milan, I953), pp. I $85-2$ I 2.

SElla, Q., Sulle condizioni dell'industria mineraria nell'isola di Sardegna (Florence, I 87 I).

Thomson, J. and A. Smith, Street Life in London (London, I876-1877), available at the Fabian Society Online Archive: https://goo.gl/SXQeiq; last accessed 7 May 20 I 8.

TurturA, D., "Per nuove più avanzate conquiste delle lavoratrici italiane", in I diritti della donna lavoratrice nella società nazionale e il riconoscimento del valore obiettivo del suo lavoro: 3 .

I 58. Following this approach: Varela, "State Policies towards Precarious Work"; Rodgers, Labour Law, Vulnerability and the Regulation of Precarious Work. 
Conferenza nazionale delle donne lavoratrici. Rome, 9-i I November 1962 (Rome, I962), pp. 9-47.

Weвb, S., Facts for Socialists from the Political Economists and Statisticians (London, 1887), available at the Fabian Society Online Archive: https://goo.gl/HRyPxZ, last accessed 7 May 2018.

Zanardelli, G., Inchiesta sulla Basilicata (Rome, 1902).

\section{Historiography}

Armstrong, P., A. Glyn, and J. Harrison, Capitalism since World War II: The Making and Breakup of the Great Boom (London, 1984).

Bigazzi, D., Il Portello. Operai tecnici e imprenditori all'Alfa Romeo 1906-1926 (Milan, I988).

Boltho, A. (ed.), The European Economy: Growth and Crisis (Oxford, 1982).

Boris, E. and A. JANSSENS, "Complicating Categories: An Introduction”, International Review of Social History, 44: Supplement 7 (1999), pp. I-I 3.

BorIs, E. and E. PrugL, Homeworkers in Global Perspective: Invisible No More (New York, I996).

Bosma, U., E. van Nederveen Meerkerk, and A. Sarkar (eds), "Mediating Labour. Worldwide Labour Intermediation in the Nineteenth and Twentieth Centuries", International Review of Social History, 57: Special Issue 20 (2012).

Botz, G. (ed.), Die Frau in der Arbeiterbewegung (Vienna, I980).

Brass, T., “'Medieval Working Practices?' British Agriculture and the Return of the Gangmaster", Journal of Peasant Studies, 3 I (2004), pp. 3 I 3-340.

Cantor, M. and B. Laurie, Class, Sex and the Woman Worker (Westport, CT, 1977).

CatTaruzza, M., La formazione del proletariato urbano. Immigrati, operai di mestiere, donne a Trieste dalla metà del secolo XIX alla prima guerra mondiale (Turin, I979).

Cooper, B., "Intersectionality", in L. Dish and M. Hawkesworth (eds), The Oxford Handbook of Feminist Theory (New York, 2015), pp. 386-406.

Crafts, N. and G. Toniolo (eds), Economic Growth in Europe since 1945 (Cambridge, 1996).

Crenshaw, K.W., "Mapping the Margins: Intersectionality, Identity Politics, and Violence against Women of Color", Stanford Law Review, 43 (I99I), pp. I 24 I-I 299.

De Clementi, A., “Appunti sulla formazione della classe operaia in Italia”, Quaderni storici, 32 (1976), pp. 684-728.

Hobsbawm, E.J., “The Machine Breakers”, Past and Present, I (1952), pp. 52-70.

Kessler-Harris, A., Out of Work: A History of Wage-Earning Women in the United States (New York, 1982).

MerLI, S., Proletariato di fabbrica e capitalismo industriale. Il caso italiano I880-I900, 2 vols (Florence, 1972).

Müller, W. et al., Strukturwandel der Framenarbeit I880-1980 (Frankfurt am Main, I983).

PatRick, J., “Agricultural Gangs in Victorian England”, History Today, 36 (1986), pp. 2 I-26.

Perrot, M. (ed.), “Travaux de femmes dans la France du XIXe siècle”, Le Mouvement Social, ros: Special Issue (1978).

Perrot, M., Les ouvriers en grève. France I $87 I_{-1} 890$ (Paris and The Hague, 1974).

Pieroni Bortolotti, F., "Le lotte delle sigaraie fiorentine dalla fondazione della Camera del lavoro all'avvento del fascismo, I893-1922”, Movimento operaio in Liguria, 6 (1960), pp. $3-22$.

PIVA, F., "Classe operaia e mobilità del lavoro in fabbrica", Studi storici, 27 (1986), pp. $245-263$.

Prugl, E., Global Construction of Gender: Home-Based Work in the Political Economy of the 2oth Century (New York, 1999). 
RapinI, A., "Can Peasants Make a Revolution? Colonialism, Labour, and Power Relations in Pierre Bourdieu’s Algerian Inquiries”, International Review of Social History, 61:3 (2016), pp. 389-42I.

Thompson, E.P., The Making of the English Working Class (London, 1963).

Tilly, L., "Paths of Proletarianization: Organization of Production, Sexual Division of Labor and Women's Collective Action”, Signs, 7 (1981), pp. 400-4I7.

Wadauer, S., T. Buchner, and A. Mejstrik (eds), The History of Labour Intermediation. Institutions and Finding Employment in the Nineteenth and Early Twentieth Centuries (New York and Oxford, 20I5).

\section{Precarious work in historical studies}

Armstead, S. et al., “'And I Poor Slave Yet': The Precarity of Black Life in New Brunswick, I 766I 835 ", in M.J. Fuentes and D. Gray White, Scarlet And Black. Slavery And Dispossession in Rutgers History (New Brunswick, NJ, 2016), pp. 91-I 22.

Atypical Works in Pre-Industrial Europe. Pluriactivity,Mobility and Social Identities. Report of Marie Curie Action: "Re-integration Grants", available at: https://goo.gl/qqs7Ja; last accessed 7 May 2018.

BEAU, S., Un siècle d'emplois précaires (Paris, 2004).

Beтti, E., "Women's Working Conditions and Job Precariousness in Historical Perspective. The Case of Italian Industry during the Economic Boom (1958-1963)", in I. Agárdi, B. Waaldijk, and C. Salvaterra (eds), Making Sense, Crafting History: Practices of Producing Historical Meaning (Pisa, 2010), pp. 175-205.

Beтti, E., "Gender and Precarious Labor in a Historical Perspective. Italian Women and Precarious Work between Fordism and Post-Fordism”, in S. Mosoetsa, C. Tilly, and J. Stillermann (eds), "Precarious Labor in Global Perspective", International Labor and Working-Class History, 89: Special Issue (2016), pp. 64-83.

CANepari, R. and C. Regnard (eds), "Abitare la città. Residenza e precarietà in età moderna e contemporanea”, Quaderni storici, I I: Thematic section (2016), pp. I03-I I 2.

De BenedetTI, A., Il masso di Sisifo. studi sull'industrializzazione in bilico (Rome, 2006).

De Viтo, C.G., "Labour Flexibility and Labour Precariousness as Conceptual Tools for the Historical Study of the Interactions among Labour Relations", in K.H. Roth (ed.), On the Road to Global Labour History: A Festschrift for Marcel van der Linden (Leiden [etc.], 2017), pp. 219-240.

Evangelisti, V. and S. Sechi, Il galletto rosso. Precariato e conflitto di classe in Emilia-Romagna I880-I 980 (Venice, I982).

KnotTer, A., "Poverty and the Family-Income Cycle. Casual Laborers in Amsterdam in the First Half of the 2oth Century", The History of the Family, 9 (2004), pp. 22 I-237.

Leleux, M., Aux sources de la précarité. L'instrumentalisation du travail dans le Nord I848-19I4 (Villeneuve d'Ascq, 2015).

Leleux, M., Histoire des sans-travail et des précaires du Nord (Villeneuve d'Ascq, 2013).

Linden, M. van DER, "San Precario: A New Inspiration for Labor Historians", Labor: Studies in Working-Class of the Americas, I I (2014), pp. 9-2 I.

SHAuKat, S.E., "Emigrer et travailler en Valais au rythme des saisons. Une histoire d'exclusion”, in L. van Dongen and G. Favre (eds), Mémoire ouvrière, (Sierre, 20I I), pp. 79-9I.

Thörnquist, A. and Å.-K Engstrand, Precarious Employment in Perspective. Old and New Challenges to Working Conditions in Sweden (Brussels, $201 \mathrm{I}$ ).

\section{Definition and conceptualization of precarious work}

Barbier, J.-C., 'Precariousness' of Employment: Linguistic and Conceptual Differences, Political Discourse and Academic Debate in Five Countries, Germany, Spain, France, Italy and the $U K$, ESOPE Project (Munich, 2002). 
Barbier, J.-C., “'Employment Precariousness' in a European Cross-national Perspective. A Sociological Review of Thirty Years of Research”, CES Working Paper (201 I).

BARBIER, J.-C., "La précarité, une catégorie française à l'épreuve de la comparaison internationale", Revue française de sociologie, 46 (2005), pp. 35 I-37I.

BArbier, J.-C., “There is More to Job Quality than 'Precariousness': A Comparative Epistemological Analysis of the 'Flexibility and Security' Debate in Europe”, in R. Muffels (ed.), Flexibility and Employment Security in Europe: Labour Markets in Transition (Cheltenham, 2008), pp. 3 I-50.

BETTI, E., "La precarietà del lavoro come fenomeno storico: un approccio di genere", Memoria e Ricerca, 40 (2014), pp. I5 I-I7I.

Bourdieu, P., "La précarité est aujourd'hui partout”, in P. Bourdieu, Contre-feux (Paris, I998), pp. 95-101.

Bourdieu, P., Travail et travailleurs en Algérie (Paris and The Hague, 1963).

Breman, J., “A Bogus Concept?”, New Left Review, 84 (2013), pp. I $30-138$.

Butler, J., Precarious Life: The Power of Mourning and Violence (New York, 2004).

Butler, J., "Performativity, Precarity and Sexual Politics", AIBR, Revista de Antropologia Iberoamericana, 3 (2009), pp. i-xiii, available at: https://goo.gl/EXMWkC; last accessed 7 May 2018.

Candeias M., "Genealogie des Prekariats”, in C. Altenhain et al. (eds), Von 'Neuer Unterschicht' und Prekariat. Gesellschaftliche Verbältnisse und Kategorien im Umbruch. Kritische Perspektiven auf aktuelle Diskurse (Bielefeld, 2008), pp. I $2 \mathrm{I}-\mathrm{I} 38$.

Casas-Cortés, M., “A Genealogy of Precarity: A Toolbox for Rearticulating Fragmented Social Realities in and out of the Workplace", Rethinking Marxism: A Journal of Economics, Culture E Society, 26 (2014), pp. 206-226.

CIAT-OIT and Ministerio de Trabajo y Seguridad Social, El empleo precario en Argentina (Lima, I988).

Düll, N., Defining and Assessing Precarious Employment in Europe: A Review of Main Studies and Surveys (Munich, 2004).

European Parliament, Directorate-General for Internal Policies, Policy Department A: Economic and Scientific Policy, Precarious Employment in Europe, Part I: Patterns, Trends and Policy Strategies (Brussels, 2016).

European Commission, Directorate-General for Employment, Social Affairs and Equal Opportunities, Study on Precarious Work and Social Rights, Final Report (201 2).

European Commission, Directorate-General for Research, FP5, Precarious Employment in Europe: A Comparative Study of Labor Market Related Risks in Flexible Economies, ESOPE Final Report (2004).

Faguer, J.P., "Pour une histoire de la précarité. Transformation des emplois précaires et mode de management", Lettre du Centre d'études de l'emploi, 57 (1999).

Hewison, K., "Precarious Work", in S. Edgell, H. Gottfried, and E. Granter (eds), The Sage Handbook of the Sociology of Work and Employment (Thousand Oaks, CA, 20I6), pp. $428-443$.

Jonna, R.J. and J.B. Foster, "Marx's Theory of Working-Class Precariousness - And Its Relevance Today", in "Precarious Work and the Struggle for Living Wages", Alternate Routes, 27: Special Issue (2016), pp. $2 \mathrm{I}-45$.

Kalleberg, A.L., "Measuring Precarious Work: A Working Paper of the EINet Measurement Group”, Chicago SSA, 2014.

Letourneux, V., Precarious Employment and Working Conditions in Europe (Luxembourg, I998).

Linden, M. VAN DER, “Robert Castel's Les métamorphoses de la question sociale (1995)”, International Labor and Working-Class History, 89 (2016), pp. I53-161. 
McKAY, S., "Disturbing Equilibrium and Transferring Risk: Confronting Precarious Work”, in N. Countouris and M. Freedland (eds), Resocialising Europe in a Time of Crisis, (Cambridge, 20I3), pp. I9I-2 I 2.

Millar, K.M., “Toward a Critical Politics of Precarity”, Sociology Compass, I I (2017), el 2483 , available at: https://doi.org/IO.I I I I/soc4.I 2483; last accessed 7 May 20 I 8.

Motakef, M., Prekarisierung (Bielefeld, 20I 5 ).

Olsthoorn, M., "Measuring Precarious Employment: A Proposal for Two Indicators of Precarious Employment Based on Set-Theory and Tested with Dutch Labor Market-Data", Social Indicators Research, I I 9 (2014), pp. $42 \mathrm{I}-44 \mathrm{I}$.

Quinlan, M., “The 'Pre-invention' of Precarious Employment: The Changing World of Work in Context", Economic and Labour Relations Review, 4 (20I 2), pp. 3-23.

Rodgers, G., "Precarious Work in Western Europe: The State of the Debate”, in G. Rodgers, and J. Rodgers (eds), Precarious Jobs in Labour Market Regulation. The Growth of Atypical Employment in Western Europe (Geneva, 1989), pp. I-16.

Rodgers, G. and J. Rodgers (eds), Precarious Jobs in Labour Market Regulation. The Growth of Atypical Employment in Western Europe (Geneva, 1989).

Seymour, R., "We are All Precarious - On the Concept of the 'Precariat' and its Misuses", New Left Project, 20I 2, available at: https://goo.gl/YKs I 57; last accessed 7 May 2018.

Sylos Labini, P., "Precarious Employment in Sicily", International Labour Review, 89 (I964), pp. 268-285.

Sylos Labini, P., Saggio sulle classi sociali, (Rome, I974).

Vultur, M., "La précarité. Un 'concept fantôme' dans la réalité mouvante du monde du travail”, SociologieS, (2010), available at: http://sociologies.revues.org/3287; last accessed 7 May 2018.

Waite, L., “A Place and Space for a Critical Geography of Precarity?”, Geography Compass, 3 I I (2009), pp. 4I 2-433.

\section{Precarious work, capitalism, and globalization}

Bassolino, A., Il lavoro possibile (Rome, 1986).

Beck U., The Brave New World of Work (Cambridge, 2000); original German version: Schöne nene Arbeitswelt. Vision: Weltbürgergesellschaft (Frankfurt am Main, 1999).

BЕск, U., Risikogesellschaft. Auf dem Weg in eine andere Moderne (Frankfurt am Main, 1986).

Berardi, F., And: Phenomenology of the End (South Pasadena, CA, 2015).

Beтti, E., "Precarious Work: Norm or Exception of Capitalism? Historicizing a Contemporary Debate: A Global Gendered Perspective", in E. Betti and K. Miller (eds), The Power of the Norm. Fragile Rules and Significant Exceptions, Institut für die Wissenschaften vom Menschen, Junior Visiting Fellows' Conference, 35, 2016, available at: https://goo.gl/ 3iArer; last accessed 7 May 2018.

Boltanski, L. and È. Chiapello, Le nouvel esprit du capitalisme (Paris, I999).

Breman, J. and M. van der Linden, "Informalizing the Economy: The Return of the Social Question at a Global Level”, Development and Change, 45 (2014), pp. 920-940.

CASTEL, R., Les métamorphoses de la question sociale. Une chronique du salariat (Paris, 1995).

Castles, S., "Migration, Precarious Work, and Rights: Historical and Current Perspectives", in C.-U. Schierup, R. Munck, B. Likic-Brboric, and A. Neergaard (eds), Migration, Precarity, and Global Governance: Challenges and Opportunities for Labour (Oxford, 20I5), pp. 46-67.

ChAn, S., “'I am King': Financialisation and the Paradox of Precarious Work”, The Economic and Labour Relations Review, 24 (2013), pp. 362-379.

Cocco, G. and B. Szaniecki, Creative Capitalism, Multitudinous Creativity. Radicalities and Alterities (Lanham, MD, 2015). 
Curtin, M. and K. SAnson (eds), Precarious Creativity: Global Media, Local Labor (Oakland, CA, 2016).

Demaret, L., "Editorial. ILO Standards and Precarious Work: Strengths, Weaknesses and Potential”, International Journal of Labour Research, 5 (2013), pp. 9-2 I.

Dennis, A. and J. Pickles, "Global Work, Surplus Labor, and the Precarious Economies of the Borders", Antipode, 43 (201 I), pp. I 598-1624.

Dyer-Witheford, N., Cyber-Proletariat: Global Labour in the Digital Vortex (London, 201 5 ).

Emmenegger, P. et al. (eds), The Age of Dualization: The Changing Face of Inequality in Deindustrializing Societies (Oxford, 201 2).

ForNäs, J., "Capitalism: Current Crisis and Cultural Critique”, Culture Unbound: Journal of Current Cultural Research, 6 (2014), pp. I $5-38$.

Frade, C. and I. Darmon, "New Modes of Business Organization and Precarious Employment: Towards the Recommodification of Labour?", Journal of European Social Policy, is (2005), Pp. I07-I 2 I.

Gallie, D., Crompton, R., and K. Purcell (eds), Changing Forms of Employment. Organisations, Skills and Gender (London, I996).

Hall, P. and D. Soskice (eds), Variations of Capitalism (Oxford, 200I).

Heery, E. and J. Salmon (eds), The Insecurity Workforce (London, 1996).

Huws, U., Labor in the Global Digital Economy (New York, 2014).

International Labour Office (ILO), Non-Standard Employment around the World: Understanding Challenges, Shaping Prospects (Geneva, 2016).

International Labour Organization (ILO), The Changing Nature of Jobs: World Employment Social Outlook (Geneva, 2015).

International Metalworkers' Federation (IMF), Survey on Changing Employment Practices and Precarious Work (Geneva, 2007).

Kalleberg, A.L. and S.P. Vallas (eds), Precarious Work: Causes, Characteristics, and Consequences (Research in the Sociology of Work, vol. 31) (Bingley, 2018).

Kalleberg, A.L, "Globalization and Precarious Work”, Contemporary Sociology, 42 (2013), pp. 700-706.

Marín, E., "Precarious Work: An International Problem", International Journal of Labour Research, 5 (2013), pp. I53-168.

Meehan, K. and K. Strauss (eds), Precarious Worlds: Contested Geographies of Social Reproduction (Athens, GA, and London, 2015).

Munck, R., “The Precariat: A View from the South", Third World Quarterly, 34 (2013), pp. 747762.

Neilson, B. and N. Rossiter, "Precarity as a Political Concept, or, Fordism as Exception", Theory, Culture E Society, 25 (2005), pp. 5 I-72.

Lee, C.K. and Y. Kofman, “The Politics of Precarity: Views Beyond the United States”, Work and Occupations, 39 (2012), pp. 388-408.

Rachwae, T., Precarity and Loss: On Certain and Uncertain Properties of Life and Work (Wiesbaden, 2017).

Rodgers, L., Labour Law, Vulnerability and the Regulation of Precarious Work (Cheltenham, 2016).

Ross, A., Nice Work If You Can Get It: Life and Labor in Precarious Times (New York, 2009).

SennetT, R., The Corrosion of Character: The Personal Consequences of Work in the New Capitalism (London, I998).

Standing, G., The Precariat: The New Dangerous Class (London and New York, 201 I).

STYHRE, A., Precarious Professional Work: Entrepreneurialism, Risk and Economic Compensation in the Knowledge Economy (Cham, 2017). 
Sverke, M., J. Hellgren, and K. Näswall, Job Insecurity: A Literature Review (Stockholm, 2006).

Thelen, K., Varieties of Liberalization and the New Politics of Social Solidarity (Cambridge, 20I4).

Thornley, C., S. JefFerys, and C. Appay, Globalisation and Precarious Forms of Production and Employment (Cheltenham, 2010).

Tsianos, T. and D. Papadopoulos, A Savage Journey to the Heart of Embodied Capitalism, (Linz, 2006), available at: https://goo.gl/ndXSM5; last accessed 7 May 2018.

WeIL, D., The Fissured Workplace: Why Work Became so Bad for so Many and What Can Be Done to Improve It (Cambridge, MA, 2014).

\section{Precarious work, flexibility, flexicurity}

Andersen, S.K., N. Lubanski, and O.K. Pedersen, The Competitiveness of the Nordic Countries: From Flexicurity to Mobication (Copenhagen, 20 I I).

Atkinson, J., "Manpower Strategies for Flexible Organisations", Personnel Management, i6 (August 1984), pp. 28-3I.

Atkinson, J. and N. Meager, Changing Work Patterns: How Firms Achieve Flexibility to Meet New Needs (London, 1996).

AuER, P., "What's in a Name? The Rise (and Fall?) of Flexicurity", Journal of Industrial Relations, 52 (2010), pp. 37I-386.

AuER, P., "In Search of Optimal Labour Market Institutions”, in H. Jørgensen and P.K. Madsen (eds), Flexicurity and Beyond. Finding a New Agenda for the European Social Model (Copenhagen, 2007), pp. 67-98.

BARBIER, J.C. and H. NADEL, La flexibilité du travail et de l'emploi (Paris, 2000).

BARBIERI, P., "Flexible Employment and Inequality in Europe", European Sociological Review, 25 (2009), pp. $62 \mathrm{I}-628$.

Berton, F., M. Richiardi, and, S. Sacchi, Flex-insecurity. Perché in Italia la flessibilità diventa precarietà (Bologna, 2009).

Boudier, A., "New Forms of Employment and Their Use in the Employment Policies of the Member States of the European Community", International Journal of Comparative Labour Law and Industrial Relations, 5 (1989), pp. I-I6.

Boyer, R. and E. Wolleb (eds), La flexibilité du travail en Europe (Paris, 1986).

Broughton, A. and I. Biletta Kullander, Flexible Forms of Work: 'Very Atypical' Contractual Arrangements (Dublin, 2010).

Bruegel, I. and A. Hegewisch, "Flexibilization and Part-Time Work in Europe", in P. Brown and R. Crompton (eds), Economic Restructuring and Social Exclusion: A New Europe? (London, 1994), pp. 33-57.

Burrows, R., N. Gilbert, and A. Pollert (eds), Fordism and Flexibility: Divisions and Change, (London, 1992).

Caire, G., "Précarisation des emplois et régulation du marché du travail”, Sociologie du Travail, 2 (I982), pp. I35-I 58.

Cazes, S. and A. Nesporova (eds), Flexicurity: A Relevant Approach in Central and Eastern Europe (Geneva, 2007).

D. Grip, A., J. Hoevenberg, and E. Willems, “Atypical Employment in the European Union”, International Labour Review, I36 (1997), pp. 49-7I.

D. Vos, M., "European Flexicurity and Globalization: A Critical Perspective," The International Journal of Comparative Labour Law and Industrial Relations, 25 (2009), pp. 209-235.

European Commission, Flexibility and Competitiveness: Labour Market Flexibility, Innovation and Organisational Performance (FLEX-COM), Final Report (Brussels, 2005). 
European Commission, Modernising Labour Law to Meet the Challenges of the 2 Ist Century, $\operatorname{COM}(2006) 708$ final (Brussels, 2006).

European Commission, Towards Common Principles of Flexicurity. More and Better Jobs Through Flexibility and Security (Luxembourg, 2007).

European Foundation for the Improvement of Working and Living Conditions, "Varieties of Flexicurity: Reflections on Key Elements of Flexibility and Security”, Background Paper, (Dublin, 2007).

European Trade Union Confederation (ETUC), “The Flexicurity Debate and the Challenges for the Trade Union Movement”, Brussels, 2007.

Evans, S. and R. Lewis, "Deregulating Labour Markets and Industrial Relations in British and U. S. Construction", International Journal of Comparative Labour Law and Industrial Relations, 4 (1988/89), pp. 248-262.

Gallino, L., Il costo umano della flessibilità (Rome-Bari, 200I).

Garibaldo, F. (ed.), Flessibili o marginali? Le nuove forme di lavoro in Italia e in Europa (Rome, I992).

Hepple, B.A., "Some Problems of Comparing Socialist and Capitalist Systems of Labour Law", International Journal of Comparative Labour Law and Industrial Relations, I (1985), pp. $235-240$.

Heyes, J., "Flexicurity in Crisis: European Labour Market Policies in a Time of Austerity", European Journal of Industrial Relations, 19 (2013), pp. 7 $1-86$.

Ivanov, S.A., "Hiring and Dismissal under Soviet Labour Law", International Journal of Comparative Labour Law and Industrial Relations, 3 (1987), pp. 97-108.

Keune, M., Bargaining for Social Rights (BARSORI): Trade Union Responses to Precarious Work, Overview Report, European Commission, 2010, available at: https://tinyurl.com/ y9oh 5 ban; last accessed 7 May 2018.

Koshiro, K., Employment Security and Labor Market Flexibility. An International Perspective (Detroit, MI, 1992).

Madsen, P.K., "The Danish Model of Flexicurity: Experiences and Lessons", Transfer, 10 (2004), pp. $187-207$.

Meulders, D. and B. Tytgat, "Atypical Employment in EEC Countries", The International Journal of Comparative Labour Law and Industrial Relations, 5 (I989), pp. 6 I-8 I.

Meulders, D. and L. Wilkin, "Labour Market Flexibility: Critical Introduction to an Analysis of a Concept", Labor and Society, I 2 (1987), pp. 3-17.

Muffels, R., Flexibility and Employment Security in Europe. Labour Markets in Transition, (Cheltenham, 2008).

Näтtı J., “Temporary Employment in the Nordic Countries: A 'Trap' or a 'Bridge'?”, Work, Employment E Society, 7 (1993), pp. 45 I-464.

OfFredi, C., "La précarité des années quatre-vingt ou un phénomène social en gestation dans la société", Revue internationale d'action communautaire, I9/59 (1988), pp. 2 I-32.

Organisation for Economic Development and Co-operation in Europe (OECD), Flexibility in the Labour Market. The Current Debate (Paris, 1986).

Paugam, S., Le salarié de la précarité (Paris, 2000).

Piore, M.L., "Perspectives on Labor Market Flexibility", Industrial Relations, 25 (1986), pp. I46-I66.

Pollert, A. (ed.), Farewell to Flexibility (Oxford, 1991).

Possenti, I., Flessibilità. Retoriche e politiche di una condizione contemporanea (Verona, 20I 2).

Rosenberg, S., "Labor Market Restructuring in Europe and the United States: The Search for Flexibility", in S. Rosenberg (ed.), The State and the Labor Market (New York, I989), pp. 3-16.

Rosenberg, S., From Segmentation to Flexibility, (Geneva, 1987). 
SAlmieri, L., "Job Insecurity, Flexibility and Home-Work Balance for Italian Couples in Nonstandard Work: The Effects of Social Class", European Review, I7 (2009), pp. 93-I 20.

Sargeant, M. and M. OrI (eds), Vulnerable Workers and Precarious Working (Newcastle upon Tyne, 20I3).

Standing, G. (ed.), In Search of Flexibility: The New Soviet Labour Market (Geneva, I99I).

Standing, G., Global Labour Flexibility: Seeking Distributive Justice (London, 1999).

STAnding, G., "Labour Flexibility: Cause or Cure for Unemployment?”, Public Lecture No. 25 , International Institute for Labour Studies, Geneva, I 986.

Supiot, A. (ed.), Au-delà de l'emploi. Transformations du travail et devenir du droit du travail en Europe (Paris, 1999).

TARLING, R. (ed.), Flexibility in the Labour Markets (London, 1987).

Trif, A., A. Koukiadaki, and M. KahancovÁ, The Rise of the Dual Labour Market: Fighting Precarious Employment in the New Member States Through Industrial Relations (PRECARIR), European Commission, 2016, available at: https://goo.gl/It6GsB; last accessed 7 May 2018.

Tros, F., "Flexicurity in Europe: Can it Survive a Double Crisis?", Proceedings of the I6th ILERA World Congress: Beyond Borders: Governance of Work in a Global Economy (Philadelphia, $\mathrm{PA}, 20 \mathrm{I} 2)$.

VAn Der Veen, R., M. Yerkes, and P. Achterberg (eds), The Transformation of Solidarity: Changing Risks and the Future of the Welfare State (Amsterdam, 20I 2).

Veitch, K. and T. KоткAs (eds), Social Rights in the Welfare State: Origins and Transformations (London, 2016).

Wedderburn, B., "Deregulation and Labour Law in Britain and Western Europe", The International Journal of Comparative Labour Law and Industrial Relations, 4 (1988/89), pp. I9I-205.

Wilthagen, T., "Flexicurity: A New Paradigm for Labour Market Policy Reform?”, Social Science Research Center Berlin, Discussion Paper No. FS I 198-202, Berlin, 1998.

Wilthagen, T., Flexicurity Practices, (Brussels, 2007).

Wilthagen, T. and R. Rogowski, "The Legal Regulation of Transitional Labour Markets" in G. Schmid and B. Grazier (eds), The Dynamics of Full Employment (Cheltenham, 2002), pp. $233-273$.

\section{Precarious work, gender, and feminism}

Altieri, G., “'New economy', lavori 'atipici’ e conseguenze di genere”, Il diritto del mercato del lavoro, 2 (200I), pp. $25 \mathrm{I}-26 \mathrm{I}$.

Alves de Matos. P., "Gender Commodification and Precarity in Portuguese Call Centres: The (Re)Production of Inequality”, Etnográfica, I 8 (2014), pp. 5-32.

Aulenbacher, B., B. Riegraf, and S. VölKer, Feministische Kapitalismuskritik. Einstiege in bedeutende Forschungsfelder (Münster, 2015).

Bonfiglioli, C., "Gender, Labour and Precarity in the South East European Periphery: The Case of Textile Workers in Štip”, Contemporary Southeastern Europe, I (2014), pp. 7-23.

Boris, E. and L. Dodson, "Working at Living: The Social Relations of Precarity", University of California at Santa Barbara, Department of Feminist Studies, 2013, available at: https:// goo.gl/NJWyMV; last accessed 7 May 2018.

Bruni, A. and G. Selmi, "Da San Precario a WonderQueer. Rappresentazioni di genere nell'attivismo precario italiano", Studi Culturali, 3 (2010), pp. 365-384.

Chan, S. and D. TweEde, "Precarious Work and Reproductive Insecurity", Social Alternatives, 34 (2015), pp. 5-I 3 .

Censis (ed.), L'impatto della flessibilità sui percorsi di carriera delle donne (Milan, 2000). 
Cole, A. and V. Hattam, "What Works?”, WSQ: Women's Studies Quarterly, 45 (2017), pp. I $5-33$.

Constable, N., "Migrant Motherhood, 'Failed Migration', and the Gendered Risks of Precarious Labour”, TRaNS: Trans-Regional and-National Studies of Southeast Asia, 3 (201 5), pp. I35-ISI.

Dawkins, N., "Do-It-Yourself: The Precarious Work and Postfeminist Politics of Handmaking (in) Detroit", Utopian Studies, 22 (20I I), pp. 26I-284.

D. Cori, P., "Comparing Different Generations of Feminists: Precariousness versus Corporations?", Feminist Review, 87 (2007), pp. I36-I40.

European Institute for Gender Equality (EIGE), Gender, Skills and Precarious Work in the EU (Vilnius, 2017).

EL-TAYeb, F., “Making Do: Survival Strategies under Precarity”, Department of Feminist Studies, University of California at Santa Barbara, 2013.

FANTONE, L. (ed.), Genere e precarietà (Naples, $20 \mathrm{I}$ I).

Fantone, L., "Precarious Changes: Gender and Generational Politics in Contemporary Italy", Feminist Review, 87 (2007), pp. 5-20.

Federici, S., "Precarious Labor: A Feminist Viewpoint", In the Middle of a Whirlwind (2014), available at: https://goo.gl/LLSmhH; last accessed 7 May 2018.

Figart, D. and E. MutARI, "Global Feminization and Flexible Labour Markets: Gendered Discourse in the Opposition to Pay Equity Reform”, in J. Gregory, R. Sales, and A. Hegewisch (eds), Women, Work and Inequality: The Challenge of Equal Pay in a Deregulated Labour Market (Houndmills and London, 1999), pp. 44-57.

FInk, D. et al. (eds), Prekarität und Freiheit? Feministische Wissenschaft, Kulturkritik und Selbstorganisation (Münster, 2013).

Fudge, J. and R. Owen (eds), Precarious Work, Women and the New Economy: The Challenge to Legal Norms (Oxford, 2006).

Gutiérrez-Rodríguez, E., "The Precarity of Feminisation: On Domestic Work, Heteronormativity and the Coloniality of Labour", International Journal of Politics, Culture, and Society, 2 (2014), pp. I9I-202.

Gutierrez-Rodriguez, E., Migration, Domestic Work and Affect: A Decolonial Approach on Value and the Feminization of Labor (New York and London, 2010).

Hatcher, J. and T.L.N. Tu, “'Make What You Love': Homework, the Handmade, and the Precarity of the Maker Movement", WSQ: Women's Studies Quarterly, 45 (2017), pp. $27 \mathrm{I}-286$.

Hatton, E., The Temp Economy: From Kelly Girls to Permatemps in Postwar America (Philadelphia, PA, 20I I).

Hellgren Z., "Markets, Regimes, and the Role of Stakeholders: Explaining Precariousness of Migrant Domestic/Care Workers in Different Institutional Frameworks", Social Politics: International Studies in Gender, State and Society, 22 (2015), pp. 220-24I.

HiLl, S., "Precarity in the Era of \#BlackLivesMatter", WSQ: Women's Studies Quarterly, 45 (2017), pp. 94-109.

Hobson, B. and L. Bede, "Precariousness and Capabilities: Migrant Care/Domestic Workers in Two Institutional Contexts", Teorija in Praksa, 52 (201 5), pp. 327-349.

International Trade Union Confederation (ITUC), Living with Economic Insecurity: Women in Precarious Work (Brussels, 201 I).

Komlosy, A., "Work and Labour Relations", in J. Kocka and M. van der Linden (eds), Capitalism: The Re-Emergence of a Historical Concept (London, 2016), pp. 33-69.

LindtNer, S., "Laboratory of the Precarious: Prototyping Entrepreneurial Living in Shenzhen”, WSQ: Women's Studies Quarterly, 45 (2017), pp. 287-305.

Lorey, I., State of Insecurity: Government of the Precarious (London and New York, 201 5 ). 
Mayer-Ahuja, N., “Three Worlds of Cleaning: Women's Experiences of Precarious Labor in the Public Sector, Cleaning Companies and Private Households of West Germany, 1973I998", Journal of Women's History, I6 (2004), pp. I I6-I4 I.

Mitropoulos, A., "Precari-Us?", European Institute for Progressive Cultural Policies, March 2005, available at: http://eipcp.net/transversal/0704/mitropoulos/en; last accessed 7 May 2018.

Morini, C., Per amore o per forza. Femminilizzazione del lavoro e biopolitiche del corpo (Verona, 20I0).

Nannicini, A., Le parole per farlo. Donne al lavoro nel post-fordismo (Rome, 2002).

Precarias a la Deriva, $A$ la deriva por los circuitos de la precariedad femenina (Madrid, 2004).

PuAr, J. (ed.), "Precarity Talk, A Virtual Roundtable with Laurent Berlant, Judith Butler, Bojana Cvejić, Isabell Lorey, Jasbir Puar, and Ana Vujanović”, The Drama Review, 56 (2012), pp. I63-177.

Vosko, L.F., Managing the Margin: Gender, Citizenship and International Regulation of Precarious Employment (Oxford, 2010).

Vosко, L.F., Temporary Work: The Gendered Rise of a Precarious Employment Relationship (Toronto, 2000).

\section{Precarious work, informality, and free/unfree labour}

Agarwala, R. and J.J. Chun, "Global Labour Politics in Informal and Precarious Jobs", in S. Edgell, H. Gottfried, and E. Granter (eds), The SAGE Handbook of Sociology of Work and Employment (New York, 2015), pp. 634-650.

Agarwala, R., Informal Labor, Formal Politics, and Dignified Discontent in India (New York, 20I3).

Amin, S. and M. van deR Linden (eds), "Peripheral Labour. Studies in the History of Partial Proletarianization”, International Review of Social History, 41: Supplement 4 (1996).

Andrees, B. and P. Belser (eds), Forced Labor: Coercion and Exploitation in the Private Economy (Geneva 2009).

Arnold, D. and J.R. Bongiovi, "Precarious, Informalizing, and Flexible Work: Transforming Concepts and Understandings", American Behavorial Scientist, 57 (2013), pp. 289-308.

BALes, K., Disposable People: New Slavery in the Global Economy (Berkeley, CA, I999).

BARCHIESI, F., "Informality and Casualization as Challenges to South Africa's Industrial Unionism: Manufacturing Workers in the East Rand/Ekurhuleni Region in the I990s”, African Studies Quarterly, I I (2010), pp. 67-85.

Benjamin, P., “The Persistence of Unfree Labour: The Rise of Temporary Employment Agencies in South Africa and Namibia", in J. Fudge and K. Strauss (eds), Temporary Work, Agencies, and Unfree Labour: Insecurity in the New World of Work (London and New York, 2013), pp. I I 8-I 42 .

Bhattacharya, S. and J. Lucassen (eds), Workers in the Informal Sector. Studies in Labour History I 800-2000, (New Delhi, 2005).

Boels, D., The Informal Economy: Seasonal Work, Street Selling and Sex Work (Cham, 2016).

Brass, T., Labour Regime Change in the Twenty-First Century. Unfreedom, Capitalism and Primitive Accumulation (Amsterdam, 201 I).

Breman, J., At Work in the Informal Economy of India. A Perspective from the Bottom Up (Oxford, 2013).

Breman, J., Circulation and Informalization of the Workforce at the Bottom of the Economy (Oxford, 2010).

Breman, J., Footloose Labour: Working in India's Informal Economy (Cambridge, 1996). 
Burchielli, R., Delaney, A., and N. Goren, "Garment Homework in Argentina: Drawing Together the Threads of Informal and Precarious Work", Economic and Labour Relations Review, 25 (2014), pp. 63-80.

Carré, F., R. Negrete, Vanek J., "Relating Quality of Employment to Informal Employment”, WIEGO Working Paper, s (2016), available at: http://www.wiego.org/wiego/wiegoworking-paper-series, last accessed 7 May 2018.

Chalmoub, S., "The Precariousness of Freedom in a Slave Society (Brazil in the Nineteenth Century)", International Review of Social History, 56 (201 I), pp. 405-439.

Chang, D., "Informalising Labour in Asia's Global Factory, Journal of Contemporary Asia, 39 (2009), pp. I6I-I79.

Chen, M.A., “The Informal Economy: Definitions, Theories and Policies”, WIEGO Working Paper, I (20I2), available at: http://www.wiego.org/wiego/wiego-working-paper-series, last accessed 7 May 2018.

Das, V. and S. Randeria, "Politics and the Urban Poor: Aesthetics, Ethics, Volatility, Precarity", Current Anthropology, 56: Supplement I I (201 5), pp. 3-I4 (Introduction).

EcKert, A. (ed.), Global Histories of Work (Berlin, 2016).

EcKert, A., "Capitalism and Labour in Sub-Saharan Africa", in J. Kocka and M. van der Linden (eds), Capitalism: The Re-Emergence of a Historical Concept (London, 2016), pp. 165-1 86.

Gerrard, J., Precarious Enterprise on the Margins. Work, Poverty, and Homelessness in the City (New York, 2017).

International Union of Food, Agricultural, Hotel, Restaurant, Catering, Tobacco and Allied Workers' Associations (IUF), “Precarious Work: Undermining Human Rights”, March 2010.

Johnson, C.G., "The Urban Precariat, Neoliberalization, and the Soft Power of Humanitarian Design", Journal of Developing Societies, 27 (201 I), pp. 445-475.

Kudva, N., Beneria L. (eds), Rethinking Informalization: Poverty, Precarious Jobs and Social Protection (Ithaca, NY, 2005).

Leogrande, A., "Il caporalato e le nuove schiavitù", Parolechiave, I (2016), pp. 103-108.

Lewis, H. et al., Precarious Lives: Forced Labour, Exploitation and Asylum (Bristol, 2014).

LEwIs, H. et al., "Hyper-precarious Lives. Migrants, Work and Forced Labour in the Global North", Progress in Human Geography, 29 (2015), pp. 580-600.

Lima, H.E., "Freedom, Precariousness, and the Law: Freed Persons Contracting out Their Labour in Nineteenth-Century Brazil”, International Review of Social History, 54 (2009), pp. 39I-4I6.

Mantouvalou, V., "Human Rights for Precarious Workers: The Legislative Precariousness of Domestic Labor", Comparative Labor Law and Policy Journal, 34 (201 2), pp. I33-166.

Millar, K.M., "The Precarious Present: Wageless Labor And Disrupted Life in Rio de Janeiro, Brazil”, Cultural Anthropology, 29 (2014), pp. 32-53.

Petrungaro, S., “The Fluid Boundaries of 'Work'. Some Considerations Regarding Concepts, Approaches, and South-Eastern Europe”, Südost-Forschungen, 72 (20I3), pp. 27 I-286.

Rogan, M. et al., "Informal Employment in the Global South: Globalization, Production Relations, and 'Precarity'", in A.L. Kalleberg and S.P. Vallas, (eds), Precarious Work. Causes, Characteristics, and Consequences (Bingley, 2018), pp. 307-333.

Swider, S., Building China: Informal Work and the New Precariat (Ithaca, NY, 2015).

Theron, J., "Informalization from Above, Informalization from Below: The Options for Organization", African Studies Quarterly, I I (2010), pp. 87-105.

Theron, J., "Intermediary or Employer? Labour Brokers and the Triangular Employment Relationship," Industrial Law Journal, 26 (2005), pp. 6i 8-649.

Tranberg Hansen, K. and M. VaA (eds), Reconsidering Informality: Perspectives from Urban Africa (Uppsala, 2004). 
Webster E., A.O. Britwum, Bhowmik S. (eds), Crossing the Divide. Precarious Work and the Future of Labour (Pietermaritzburg, 2017).

Woolfson, C., 'Pushing the Envelope: The “Informalization' of Labour in Post-communist New EU Member States," Work, Employment and Society, 2 I (2007), pp. 55 I-564.

\section{Precarious work, social movements, and trade unions}

ACTRAV, From Precarious Work to Decent Work. Outcome Document to the Workers' Symposium on Policies and Regulations to Combat Precarious Work (Geneva, 201 2).

Armano, E., A. Bove, and A. Murgia, Mapping Precariousness, Labour Insecurity and Uncertain Livelihoods: Subjectivities and Resistance (Abingdon, 2017).

Bodnar, C., "Taking it to the Streets: French Cultural Worker Resistance and the Creation of a Precariat Movement", Canadian Journal of Communication, 3I (2016), pp. 675-694.

Busch, M., Jeskow, J., and R. StuTZ (eds), Zwischen Prekarisierung und Protest. Die Lebenslagen und Generationsbilder von Jugendlichen in Ost und West (Bielefeld, 2010).

Choi, H.-L. and A. Mattoni, "The Contentious Field of Precarious Work in Italy: Political Actors, Strategies and Coalitions", Journal of Labor and Society, I 3 (2010), pp. 2 I 3-243.

Contarini, S., M. Jansen, and S. Ricciardi, Le culture del precariato. Pensiero, azione, narrazione (Verona, 2015).

Contarini S. and L. Marsi, Précariat. Pour une critique de la société de la précarité (Paris, 20I4).

D. SARIO, B., “'Precari su Marte': An Experiment in Activism Against Precarity”, Feminist Review, 87 (2007), pp. 2 I-39.

Della Porta, D. et al. (eds), The New Social Division: Making and Unmaking Precariousness, (London, 2015).

Doellgast, V., N. Lillie, and V. Pulignano (eds), Reconstructing Solidarity: Labour Unions, Precarious Work, and the Politics of Institutional Change in Europe (Oxford, 2018).

European Federation of Food, Agriculture and Tourism Trade Unions (EFFAT), Precarious Work in Europe. Causes and Consequences for the Agriculture, Food and Tourism Sectors (201 I).

European Federation of Food, Agriculture and Tourism Trade Unions (EFFAT), Social Justice from Farm to Fork. Fight Precarious Work! EFFAT Charter on Precarious Work (2009).

Evans, J. and E. Gibb, Moving from Precarious Employment to Decent Work, (Geneva, 2009).

Fоті, A., “The Precariat for Itself: EuroMayDay and Precarious Workers' Movements”, in E. Armano, A. Bove, and A. Murgia (eds), Mapping Precariousness, Labour Insecurity and Uncertain Livelihoods: Subjectivities and Resistance (Abingdon, 2017), pp. I49-1 56.

FoTI, A., General Theory of the Precariat. Great Recession, Revolution, Reaction (Institute of Network Cultures, Amsterdam, 2017).

Fumagalli, A., "Cognitive Relational (Creative) Labor and the Precarious Movement for 'Commonfare': 'San Precario' and EuroMayDay”, in G. Cocco and B. Szaniecki (eds), Creative Capitalism, Multitudinous Creativity. Radicalities and Alterities, (Lanham, MD, $2015)$, pp. 3-24.

Garrett, R. and L.K. Jackson, "Art, Labour and Precarity in the Age of Veneer Politics", Alternative Routes, 27 (2016) pp. 279-299.

International Metalworkers' Federation, Precarious Work Affects us All! Mobilizing Globally Against Precarious Work (2008).

Johnson, M. (ed.), Precariat: Labour, Work and Politics (London, 2016).

Keune, M., “Trade Union Responses to Precarious Work in Seven European Countries”, International Journal of Labour Research, 5 (2013), pp. 59-78.

Knotter, A., "Justice for Janitors Goes Dutch. Precarious Labour and Trade Union Response in the Cleaning Industry (I988-2012): A Transnational History", International Review for Social History, 62 (2017), pp. I-35. 
Lambert, R. and A. Herod (eds), Neoliberal Capitalism and Precarious Work. Ethnographies of Accommodation and Resistance (Cheltenham, 2016).

Mattoni, A., Media Practices and Protest Politics. How Precarious Workers Mobilise (Farnham, 20I2).

Milkman, R. and E. Отт (eds), New Labor in New York: Precarious Workers and the Future of the Labor Movement, (New York, 2014).

Murgia, A. and E. Ermano (eds), Mappe della precarietà, 2 vols (Bologna, 2012).

Murgia, A. and G. Selmi, "Inspire and Conspire. Italian Precarious Workers between SelfOrganization and Self-Advocacy", Interface: A Journal for and about Social Movements, 4 (20I 2), pp. $8 \mathrm{I}-\mathrm{I} 96$.

Marchart, O., Die Prekarisierungsgesellschaft. Prekäre Proteste. Politik und Ökonomie im Zeichen der Prekarisierung (Bielefeld, 2013).

Neilson, B. and N. Rossiter, "From Precarity to Precariousness and Back Again: Labour, Life and Unstable Networks", Fibreculture Journal, 5 (2005).

Ross, A., “The New Geography of Work: Power to the Precarious?”, Theory, Culture E Society, 25 (2008), pp. 3 I-49.

Schram, S.F., The Return of Ordinary Capitalism: Neoliberalism, Precarity, Occupy, (New York, 2015).

Schierup, C.-U., "Under the Rainbow: Migration, Precarity and People Power in Post-Apartheid South Africa”, Critical Sociology, 42 (2016), pp. 105 I-1068.

Schierup, C.-U. and M.B. Jørgensen (eds), "Politics of Precarity: Migrant Conditions, Struggles and Experiences", Critical Sociology, 42: Special Issue (2016).

Tari, M. and I. Vanni, "On the Life and Deeds of San Precario, Patron Saint of Precarious Workers and Lives", Fibreculture Journal, 5 (2005).

Trotт, B., "From the Precariat to the Multitude", Global Discourse: An Interdisciplinary Journal of Current Affairs and Applied Contemporary Thought, 3 (2013), pp. 406-425.

\section{IO. Journal issues on precarious work}

"For the global emancipation of labour: new movements and struggles around work, workers and precarity", Interface: a journal for and about social movements, 2 (201 2).

"Globalization and Labor Flexibility: The Latin American Case(s)", Latin American Perspectives, 3г:4 (2004).

"Italian Feminisms", Feminist Review, 87, 3 (2007).

"Meeting the Challenge of Precarious Work. A Worker's Agenda", International Journal of Labour Research, 5:I: Special Issue (2013).

"Precarious Situations: Race, Gender, Globality", Women E Performance: A Journal of Feminist Theory, 23:2: Special Issue (2013).

"Precarious Work and Human Rights", Comparative Labor Law and Policy Journal, 34: Special Issue (20I2).

"Precarious Work and the Struggle for Living Wages", Alternatives Routes, 27: Special Issue (20I6).

"Youth and Precarious Work", Social Alternatives, 34:4: Special Issue (201 5).

Appelbaum, E. (ed.), “Precarious Work in Polarizing Times: A Symposium on Arne L. Kalleberg's Good Jobs, Bad Jobs (Russel Sage Foundation, 2011)", Work and Occupations, 39:4: Special Issue (20I2).

Bellavitis, A. and S. Piccone Stella (eds), "Flessibili/Precarie”, Genesis, 7: I-2: Special Issue (2008).

Choudry, A. and T. Collombat (eds), "Nouvelles voix sur la précarité du travail et sur la résistance ouvrière", Labour, Capital and Society, 45:1: Special Issue (2012). 
De Simone, G. and S. SCARPONI (eds), "Genere, lavori precari, occupazione instabile”, Lavoro $e$ diritto, 24:3: Special Issue (2010).

Hewison, K. and A.L. Kalleberg (eds), "Precarious Work in South and Southeast Asia", American Behavioral Scientist, 57:4: Special Issue (2013).

Kalleberg, A.L. and K. Hewison (eds), "Precarious Work in East Asia", American Behavioral Scientist, 57:3: Special Issue (2013).

Kalleberg, A.L. and S.P. Vallas (eds), Precarious Work. Causes, Characteristics, and Consequences (Bingley, 2018).

Mosoetsa, S., C. Tilly, and J. Stillermann (eds), "Precarious Labor in Global Perspective”, International Labour and Working-Class History, 89 (2016).

Neilsen, B. and N. Rossiter (eds), "Precarious Labour", The Fibreculture Journal, 5: Special Issue (2005).

Nienhueser, W. (ed.), “Flexible Work - Atypical Work - Precarious Work?”, Management Revue, I6: Special Issue (2005).

Schierup, C.-U. and M.B. Jørgensen (eds), "Politics of Precarity: Migrant Conditions, Struggles and Experience”, Critical Sociology, 42: Special Issue (2016).

\section{I. Additional regional and national studies}

\section{Europe}

Alós, R., F. Míguelez, and A. Recio, El trabajo precario en el comercio (Barcelona, 1988).

Altenhain, C. et al. (eds), Von 'Neuer Unterschicht' und Prekariat. Gesellschaftliche Verbältnisse und Kategorien im Umbruch. Kritische Perspektiven auf aktuelle Diskurse (Bielefeld, 2008).

Brinkmann, U., K. Dörre, and S. RöBenack, Prekäre Arbeit. Ursachen, Ausmaß, soziale Folgen und subjektive Verarbeitungsformen unsicherer Beschäftigungsverbältnisse (Bonn, 2006).

BRUsCo, S., "Organizzazione del lavoro e decentramento produttivo nel settore metalmeccanico," in F.L.M. Bergamo (ed.), Sindacato e piccola impresa. Strategia del capitale e azione sindacale nel decentramento produttivo (Bari, 1975), pp. 9-67.

Castel, R. and K. Dörre, Prekarität, Abstieg, Ausgrenzung. Die soziale Frage am Beginn des 2 I. Jabrbunderts (Frankfurt am Main and New York, 2009).

Castillo, J.J. and C. Prieto, Condiciones de trabajo. Hacia un enfoque renovador de la sociología del trabajo (Madrid, 1983).

Chicchi, F., Derive sociali. Precarizzazione del lavoro, crisi del legame sociale ed egemonia culturale del rischio (Milan, 200I).

FREY, L. (ed.), Lavoro a domicilio e decentramento dell'attività produttiva nei settori tessile $e$ dell'abbigliamento in Italia (Milan, 1975).

Linhart, D. and M. Maruani, "Précarisation et déstabilisation des emplois ouvriers, quelques hypothèses", Travail et emploi, I I (1982), pp. 2 I-40.

Meldolesi, L., Disoccupazione ed esercito industriale di riserva in Italia (Bari, 1972).

PACI, M., Mercato del lavoro e classi sociali in Italia (Bologna, 1973).

Prtrou, A., La vie précaire, des familles face à leurs difficultés (Paris, 1978).

Pitrou, A., Vivre sans famille? Les solidarités familiales dans le monde d'aujourd'bui, (Toulouse, I978).

Recio, A., "Flexibilidad, eficiencia y desigualdad (notas sobre la flexibilidad laboral)", Sociología del Trabajo, 4 (1988), pp. 8I-106.

Rizza, R. (ed.), Politiche del lavoro e nuove forme di precarizzazione del lavoro, (Milan, 2000).

SÁnchez Moreno, M. and A. Cutanda Tarín, "Segmentación, flexibilidad y precarización en el mercado de trabajo de la Comunidad Valenciana”, Revista de Treball, i6 (I991), pp. I69-1 83 . 
Tiddi, A., Precari. Percorsi di vita tra lavoro e non lavoro (Rome, 2002).

Varela, R., "State Policies towards Precarious Work: Employment and Unemployment in Contemporary Portugal”, International Review of Social History, 61 (2016), pp. 263-284.

MAI, Q., "Precarious Work in Europe: Assessing Cross-National Differences and Institutional Determinants of Work Precarity in 32 European Countries", in A.L. Kalleberg and S.P. Vallas (eds), Precarious Work. Causes, Characteristics, and Consequences (Bingley, 2018), pp. 273-306.

LÉvy, C., Vivre au minimum. Enquête dans l'Europe de la précarité (Paris, 2003).

Laparra, M., La construction del empleo precario. Dimensiones, causas y tendencias de la precariedad laboral (Madrid, 2006).

Mckay, S., N. Clark, and A. Paraskevopoulou, "Precarious Work in Europe. Causes and Consequences for the Agriculture, Food and Tourism Sectors", Final Report (20I I).

Procoli, A. (ed.), Workers and Narratives of Survival in Europe: The Management of Precariousness at the End of the Twentieth Century (New York, 2004).

Offe, C. and J. Deken, "La précarité sur le marché du travail. Options politiques", in A. Pouchet (ed.), Sociologies $d u$ travail. 40 ans après (Paris, 200I), pp. 53-70.

\section{North America}

Cranford, C.J., L.F. Vosko, and N. Zukewich, "Precarious Employment in the Canadian Labour Market: A Statistical Portrait”, Just Labour. A Canadian Journal of Work and Society, 3 (2003), pp. 6-22.

De Peuter, G., "Confronting Precarity in the Warhol Economy: Notes from New York City", Journal of Cultural Economy, 7 (2014), pp. 3 I-47.

Gleeson, S., Precarious Claims: The Promise and Failure of Workplace Protections in the United States (Oakland, CA, 2016).

Kalleberg, A.L., "Precarious Work, Insecure Workers: Employment Relations in Transition”, American Sociological Review, I (2009), pp. I-22.

Kalleberg, A.L., Good Jobs, Bad Jobs: The Rise of Polarized and Precarious Employment Systems in the United States, 1970s-2000s (New York, 20I I).

Rose, D., "Economic Restructuring and the Diversification of Gentrification in the r980s: A View from a Marginal Metropolis”, in J. Caulfield and L. Peake (eds), City Lives and City Forms: Critical Research and Canadian Urbanism (Toronto, I996), pp. I3 I-172.

Schellenberg, G. and C. Clarke, Temporary Employment in Canada: Profiles, Patterns and Policy Considerations (Ottawa, I996).

\section{Australia}

Burgess, J. and I. Campbell, "The Nature and Dimensions of Precarious Employment in Australia", Labour and Industry: A Journal of the Social and Economic Relations of Work, 8 (1998), pp. 5-21.

Tweedie, D., "Precarious Work and Australian Labour Norms", The Economic and Labour Relations Review, 3 (2013), pp. 297-3 I 5.

Japan

Allison, A., “Ordinary Refugees: Social Precarity and Soul in 2 ist Century Japan”, Anthropological Quarterly, 85 (2012), pp. 345-370.

Allison, A., Precarious Japan, (Durham, NC, 2013).

GotTfried, H., “Precarious Work in Japan: Old Forms, New Risks?”, Journal of Contemporary Asia, 3 (2014), pp. 464-478.

Iwata-Weickgenannt, K. and R. Rosenbaum, Visions of Precarity in Japanese Popular Culture and Literature (London and New York, 20I4). 
Piotrowski M., A.L. Kalleberg, and R. Rindfuss, “Contingent Work Rising: Implications for the Timing of Marriage in Japan”, Journal of Marriage and Family, s (2015), pp. I0391056.

\section{Eastern Europe and Russia}

Herrmann, P., V. Bobkov, and J. Csoba (eds), Labour Market and Precarity of Employment. Theoretical Reflection and Empirical Data from Hungary and Russia (Vienna, 2014).

Walker, C., "Stability and Precarity in the Lives and Narratives of Working-Class Men in Putin's Russia", Social Alternatives, 4 (2015), pp. 28-34.

\section{China}

Kuruville, S., C.K. Lee, and M. Gallagher (eds), From Iron Rice Bowl to Informalization (Ithaca, NY, 20I I), pp. 17-35.

Xu, F., “Temporary Work in China: Precarity in an Emerging Labour Market”, in J. Fudge and K. Strauss (eds), Temporary Work, Agencies, and Unfree Labour: Insecurity in the New World of Work (London and New York, 2013), pp. 143-163.

Zhang, T.Y., "From China to the Big Top: Chinese Acrobats and the Politics of Aesthetic Labor, I950-2010", in S. Mosoetsa, C. Tilly, and J. Stillermann (eds), "Precarious Labor in Global Perspective”, International Labor and Working-Class History, 89: Special Issue (2016), pp. 40-63.

Zhou, Y., "The State of Precarious Work in China”, in A.L. Kalleberg and K. Hewison (eds), "Precarious Work in East Asia", American Behavioral Scientist, 3 (2013), pp. 354-372.

Asia

Constable, N., "Migrant Motherhood, 'Failed Migration', and the Gendered Risks of Precarious Labour", TRaNS: Trans-Regional and-National Studies of Southeast Asia, 3 (2015), pp. I35-ISI.

Hewison, K. and A.L. Kalleberg, "Precarious Work and Flexibilization in South and Southeast Asia", American Behavioral Scientist, 57 (2013), pp. 395-402.

JANG, S.-Y. et al., "Precarious Employment and New-Onset Severe Depressive Symptoms: A Population-Based Prospective Study in South Korea”, Scandinavian Journal of Work, Environment \& Health, 4I (2015), pp. 329-337.

Jung, M., "Precarious Seoul: Urban Inequality and Belonging of Young Adults in South Korea”, Positions: East Asia Cultures Critique, 25 (2017), pp. 745-767.

Kalleberg, A.L. and K. Hewison, "Precarious Work and the Challenge for Asia", American Behavioral Scientist, 57 (2013), pp. $27 \mathrm{I}-288$.

Lee, H. and R.E. Ofreneo, "From Asian to Global Financial Crisis: Recovery Amidst Expanding Labour Precarity", Journal of Contemporary Asia, 44 (2014).

Shankar, V.K. and R. SAHNI, "The Inheritance of Precarious Labor: Three Generations in Waste Picking in an Indian City”, WSQ: Women's Studies Quarterly, 25 (2017), pp. $245-262$.

SAPKAL, S.R. and K.R. SHYAm Sundar, "Determinants of Precarious Employment in India: An Empirical Analysis”, in A.L. Kalleberg and S.P. Vallas (eds), Precarious Work. Causes, Characteristics, and Consequences (Bingley, 2018), pp. 335-36r.

Africa

BARCHIESI, F., "Wage Labor, Precarious Employment, and Social Inclusion in the Making of South Africa's Postapartheid Transition", African Studies Review, 5 I (2008), pp. I I9-I 42.

Barchiesi, F., Precarious Liberation. Workers, the State and Contested Social Citizenship in PostApartheid South Africa, (New York and Durban, 201 I).

Bodibe, O. (ed), The Extent and Effects of Casualisation in Southern Africa: Analysis of Lesotho, Mozambique, South Africa, Swaziland, Zambia and Zimbabwe, Research Report for the Danish Federation of Workers, 2006, available at: https://goo.gl/HxbZAB; last accessed 7 May 2018. 
Kenny, B., "The Regime of Contract in South African Retailing: A History of Race, Gender and Skill in Precarious Labor", in S. Mosoetsa, C. Tilly, and J. Stillermann (eds), "Precarious Labor in Global Perspective”, International Labor and Working-Class History, 89: Special Issue (2016), pp. 20-39.

Smit, R. and P. Rugunanan, "From Precarious Lives to Precarious Work: The Dilemma Facing Refugees in Gauteng, South Africa”, South African Review of Sociology, 45 (20I4).

Latin America

Galin, P., “Asalariados, precarización y condiciones de trabajo”, Nueva Sociedad, 85 (1986), pp. $30-38$.

Neffa, J., "Condiciones y medio ambiente de trabajo de los trabajadores a domicilio en Argentina" (Buenos Aires, 1987).

Galín, P. and M. Novick (eds), La precarización del empleo en Argentina (Buenos Aires, 1990). Marshall, A., Formas precarias de trabajo asalariado. Dos estudios en el Área Metropolitana de Buenos Aires (Geneva, 1990).

Cortes, R., "El Trabajo clandestino en la industria del vestido", in CIAT-OIT and Ministerio de Trabajo Y Seguridad Social, El empleo precario en Argentina (Lima, 1988), pp. $75-87$.

Forero-Rodríguez, R. and R. Forero-Contreras, "Nuevas formas y aspectos de las relaciones de trabajo atípicas”, XI Congreso Internacional de Derecho del Trabajo y la Seguridad Social, Ponencias Nacionales, Tema II, vol. I (Caracas, I988).

Peñalba, S. and A. Rofman (eds), Desempleo structural, pobreza y precariedad (Buenos Aires, 1996). Lindenboim, J., "The Precariousness of Argentine Labor Relations in the I990s", Latin American Perspectives, 3I (2004), pp. 2 I-3 I.

\section{TRANSLATED ABSTRACTS FRENCH - GERMAN - SPANISH}

Eloisa Betti. En historicisant le travail précaire: quarante ans de recherche dans les sciences sociales et bumaines.

Cette enquête tente de contribuer à la compréhension des concepts de travail précaire et de précarisation dans l'histoire du capitalisme industriel, en examinant le débat dans les sciences sociales et humaines durant les quarante dernières années. Sur la base d'une approche globale de genre, l'article entend proposer une critique de la perspective globale nordique, qui conçoit en grande partie le travail précaire comme un nouveau phénomène dépourvu d'une assez longue tradition historique. La première partie examine les multiples origines, définitions et conceptualisations du "travail précaire" élaborées à propos du capitalisme industriel et post-industriel, en tenant compte de sources contemporaines sélectionnées et d'études conduites par des historiens et spécialistes des sciences sociales. Dans la seconde partie, l'influence de diverses approches, telles que les approches féministes et post-coloniales, mondialisant et générisant le débat sur le travail précaire, sont examinées dans leur contexte historique, tout en étudiant également le lien crucial du travail précaire et du travail informel. En conclusion, les limitations de la littérature disponible sont examinées et assorties de suggestions d'orientations ultérieures pour historiciser le travail précaire dans une perspective globale. 
Eloisa Betti. Historisierung der prekären Arbeit: Vierzig Jahre sozial- und geisteswissenschaftliche Forschung.

Dieser Überblicksartikel soll einen Beitrag zum Verständnis der Begriffe der prekären Arbeit sowie der Prekarisierung innerhalb der Geschichte des Industriekapitalismus leisten, indem er sich mit der innerhalb der Sozial- und Geisteswissenschaften während der letzten vierzig Jahre geführten Debatte auseinandersetzt. Ausgehend von einem gendersensiblen, globalen Ansatz zielt der Artikel auf die Formulierung einer Kritik jener auf den globalen Norden zentrierten Perspektive, die prekäre Arbeit weitgehend als neues Phänomen ohne weiter zurückreichende historische Tradition auffasst. Im ersten Teil werden die vielfachen Ursprünge, Definitionen und Konzeptualisierungen der »prekären Arbeit« diskutiert, und das in Hinblick sowohl auf den Industrie- als auch auf den postindustriellen Kapitalismus. Dabei werden ausgewählte zeitgenössische Quellen ebenso berücksichtigt wie von Historikern und Sozialwissenschaftlern vorgelegte Studien. Im zweiten Teil wird der Einfluss verschiedener Ansätze, etwa des feministischen und des postkolonialen, untersucht. Es wird, unter Berücksichtigung des jeweiligen historischen Kontexts, die Frage erörtert, wie solche Ansätze die Debatte um prekäre Arbeit für Genderthemen geöffnet und globalisiert haben. Dabei wird auch dem Zusammenhang von prekärer und informeller Arbeit nachgegangen, der von ausschlaggebender Bedeutung ist. Im Schlussteil werden die Defizite der vorliegenden Literatur diskutiert; außerdem werden Vorschläge unterbreitet, wie die prekäre Arbeit noch weitgehender und aus globaler Perspektive zu historisieren wäre.

Übersetzung: Max Henninger

Eloisa Betti. Historizando el trabajo precario: Cuarenta años de investigación en las ciencias sociales y las humanidades.

Este artículo tiene por objetivo el contribuir a la comprensión de los conceptos de trabajo precario y precarización a lo largo de la historia del capitalismo industrial abordando el debate habido en las ciencias sociales y las humanidades a lo largo de los últimos cuarenta años. Basado en una aproximación global de género el texto trata de ofrecer una crítica de la perspectiva global nor-céntrica que concibe fundamentalmente el trabajo precario como un fenómeno nuevo que carece una tradición histórica más longeva. En la primera parte se plantean los múltiples orígenes, definiciones y conceptualizaciones del "trabajo precario" que se han elaborado en función tanto del capitalismo industrial como del post-industrial, tomando en cuenta una selección de fuentes contemporáneas y de estudios desarrollados por historiadores/as y científicos/as sociales. En la segunda parte analizamos la influencia de las diferentes perspectivas en los debates suscitados, tales como el feminismo y los estudios post-coloniales a la hora de globalizar e introducir una perspectiva de género en referencia a la cuestión del trabajo precario. Todo ello prestando atención a los contextos históricos en los que se plantean y explorando también los nexos de interrelación existentes entre el trabajo precario y el trabajo informal. A modo de conclusión, se plantean las limitaciones de la literatura disponible y se elaboran sugerencias para trazar futuras direcciones a la hora de historizar el trabajo precario desde una perspectiva global. 